\title{
Regionaal arbeidsmarkt informatie systeem Limburg : een verkennende analyse
}

Citation for published version (APA):

de Grip, A. (1993). Regionaal arbeidsmarkt informatie systeem Limburg : een verkennende analyse. Researchcentrum voor Onderwijs en Arbeidsmarkt, Faculteit der Economische Wetenschappen. ROA Reports No. 6 https://doi.org/10.26481/umarep.1993006

Document status and date:

Published: 01/01/1993

DOI:

10.26481/umarep.1993006

Document Version:

Publisher's PDF, also known as Version of record

\section{Please check the document version of this publication:}

- A submitted manuscript is the version of the article upon submission and before peer-review. There can be important differences between the submitted version and the official published version of record.

People interested in the research are advised to contact the author for the final version of the publication, or visit the DOI to the publisher's website.

- The final author version and the galley proof are versions of the publication after peer review.

- The final published version features the final layout of the paper including the volume, issue and page numbers.

Link to publication

\footnotetext{
General rights rights.

- You may freely distribute the URL identifying the publication in the public portal. please follow below link for the End User Agreement:

www.umlib.nl/taverne-license

Take down policy

If you believe that this document breaches copyright please contact us at:

repository@maastrichtuniversity.nl

providing details and we will investigate your claim.
}

Copyright and moral rights for the publications made accessible in the public portal are retained by the authors and/or other copyright owners and it is a condition of accessing publications that users recognise and abide by the legal requirements associated with these

- Users may download and print one copy of any publication from the public portal for the purpose of private study or research.

- You may not further distribute the material or use it for any profit-making activity or commercial gain

If the publication is distributed under the terms of Article $25 \mathrm{fa}$ of the Dutch Copyright Act, indicated by the "Taverne" license above, 
REGIONAAL ARBEIDSMARKT

INFORMATIE SYSTEEM LIMBURG

Een verkennende analyse

ROA-R-1993/6

A. de Grip

RESEARCHCENTRUM VOOR ONDERWIJS EN ARBEIDSMARKT

Faculteit der Economische Wetenschappen

Rijksuniversiteit Limburg

Maastricht, juli 1993 
CIP-GEGEVENS KONINKLIJKE BIBLIOTHEEK, DEN HAAG

Grip, A. de

Regionaal arbeidsmarkt informatiesysteem Limburg: een verkennende analyse / A. de Grip. Maastricht: Researchcentrum voor Onderwijs en Arbeidsmarkt, Faculteit der Economische Wetenschappen, Rijksuniversiteit Limburg. - (ROA-R-1993/6)

Met lit. opg.

ISBN 90-5321-107-1

Trefw: onderwijs en arbeidsmarkt ; informatiesystemen. 
INHOUDSOPGAVE

Bladzijde

VOORWOORD

1. INLEIDING 1

2. BESCHIKBARE REGIONALE INFORMATIEBRONNEN 4

3. BELEIDSRELEVANTE ARBEIDSMARKTINFORMATIE 13

3.1. Inleiding 13

$\begin{array}{ll}\text { 3.2. Combinatiemogelijkheden en koppelingsproblemen } & 13\end{array}$

$\begin{array}{ll}\text { 3.3. Beleidsrelevantie voor de verschillende gebruiksdoelen } & 17\end{array}$

4. CONTOUREN RAIS 24

$\begin{array}{lr}\text { LITERATUUR } & 29\end{array}$

BIJLAGE I. CONTACTPERSONEN 31 


\section{VOORWOORD}

In opdracht van de Regionale Besturen voor de Arbeidsvoorziening (RBA's) Midden- en NoordLimburg en Zuid-Limburg wordt in dit rapport verslag gedaan van een verkennende analyse naar de mogelijkheden om te komen tot een 'Regionaal Arbeidsmarkt Informatie Systeem' (RAIS), toegespitst op de informatiebehoefte van de beide RBA's. De studie is uitgevoerd door dr. A. de Grip, als hoofdonderzoeker verbonden aan het Researchcentrum voor Onderwijs en Arbeidsmarkt (ROA). Drs. M.H. Wieling assisteerde bij het in beeld brengen van de gepresenteerde regionale arbeidsmarktinformatie. Prof. dr. J.A.M. Heijke, dr. R.K.W. van der Velden en drs. E.J.T.A. Willems becommentarieerden de concept-versie van het rapport.

Met dank aan de in Bijlage I genoemde contactpersonen die nadere inlichtingen verstrekten over de bij hun organisatie beschikbare regionale arbeidsmarktinformatie, in het bijzonder ook aan drs. Th. Mensen die de in dit rapport gestelde onderzoeksvragen formuleerde en tevens optrad als contactpersoon namens de beide opdrachtgevers. 


\section{INLEIDING}

Tot op heden beperkt de op regionaal niveau beschikbare arbeidsmarktinformatie in Limburg zich tot enkele in de praktijk niet of nauwelijks aan elkaar gerelateerde databronnen, waaruit slechts in zeer beperkte mate informatie kan worden gegenereerd over de regionale arbeidsmarktontwikkelingen en -discrepanties naar bedrijfssector, beroep en/of opleiding. Voor een adequaat Arbeidsvoorzieningsbeleid is het echter van eminent belang dat men kan beschikken over actuele informatie over de regionale arbeidsmarkt, aangevuld met op verantwoorde wijze opgestelde arbeidsmarktprognoses ${ }^{1}$.

Om te kunnen komen tot een "Regionaal Arbeidsmarkt Informatie Systeem" (RAIS) voor de provincie Limburg, verbijzonderd naar de beide RBA-regio's, is het wenselijk eerst een beeld te krijgen van wat een regionaal arbeidsmarktinformatiesysteem voor de regionale Arbeidsvoorzieningsorganisatie zou kunnen betekenen, wanneer gebruik gemaakt zou worden van de momenteel beschikbare databronnen. In dit verkennende onderzoek zal worden getracht een dergelijk overzicht te geven ${ }^{2}$.

Op basis van drie eerdere verkennende analyses (Huson \& Meesters 1989, De Grip 1991 en Van der Laan 1992) komen de volgende vijf informatiebronnen naar voren als de belangrijkste databronnen voor regionale arbeidsmarktinformatie:

- Enquête Beroepsbevolking, Centraal Bureau voor de Statistiek (CBS);

- Informatiesysteem onderwijs-arbeidsmarkt, ROA;

- RUBS ${ }^{3}$-schoolverlatersenquête, Regionaal Dienstverlenend Centrum Limburg, Servicebureau schoolverlatersinformatie, ROA;

- Vestigingenregister Limburg, Economisch Technologisch Instituut Limburg (ETIL), RBA's;

- Enquête Regionale Bedrijfsontwikkeling (ERBO), Kamers van Koophandel.

Daarnaast kwam uit eerdere contacten van het ROA met de Gemeenschappelijke Medische Dienst (GMD-)Maastricht naar voren dat het in enkele GMD-regio's opgezette Bedrijfs Informatie Systeem mogelijk waardevolle arbeidsmarktinformatie bevat voor een regionaal arbeidsmarkt informatiesysteem.

De Grip (1991) en Van der Laan (1992) noemen naast bovengenoemde informatiebronnen nog enkele andere databronnen: Woningbehoefte onderzoek (CBS), Statistiek Werkzame Personen/Jaarlijks onderzoek naar Werkgelegenheid en Lonen (CBS), Vacature-enquête (CBS),

1. Zie ook Concept Nota van uitgangspunten RAIS, Maastricht 13 juli 1992.

2. Daarbij zal niet nader worden ingegaan op eventueel nieuw op te zetten meetinstrumenten, waarmee mogelijk zou kunnen worden voorzien in de bestaande informatiebehoefte, waaraan op basis van de momenteel beschikbare informatiebronnen niet of in onvoldoende mate tegemoet kan worden gekomen.

3. Registratie Uitstroom en Bestemming van Schoolverlaters. 
Regionaal Economische Jaarcijfers (CBS), Onderzoek Verplaatsingsgedrag (CBS) en de Primaire en Gemeenschappelijke Informatiesystemen (PGI) van de Arbeidsvoorzieningsorganisatie. Aangezien genoemde CBS-onderzoeken vanuit het oogpunt van de informatiebehoefte van de Arbeidsvoorzieningsorganisatie weinig of niets kunnen toevoegen aan de eerder genoemde informatiebronnen ${ }^{4}$ zal er hier niet verder op deze databronnen worden ingegaan. In een enkel geval zal er ad hoc naar deze bronnen worden verwezen. Het PGI komt hier aan de orde als de intern beschikbare informatie van de Arbeidsvoorzieningsorganisatie.

In deze verkennende studie staan de volgende vijf onderzoeksvragen centraal:

1. Welke voor de regionale Arbeidsvoorzieningsorganisatie relevante regionale arbeidsmarktinformatie bieden de beschikbare informatiebronnen?

2. Welke mogelijkheden bestaan er om de beschikbare informatiebronnen met elkaar te combineren tot relevante regionale arbeidsmarktinformatie.

3. Wat is de relevantie van deze informatie voor de drie verschillende gebruiksbehoeften van het RBA, te weten:

- het Regionaal Meerjaren Beleidsplan;

- de scholingsplanning;

- het bemiddelingsbeleid?

4. In hoeverre is een koppeling mogelijk van de bovengenoemde regionale arbeidsmarktinformatie met de intern beschikbare arbeidsmarktinformatie van de Arbeidsvoorzieningsorganisatie?

5. Welk model zou op basis van mogelijke combinaties van de beschikbare arbeidsmarktinformatie ten grondslag kunnen liggen aan een regionaal arbeidsmarktinformatiesysteem ten behoeve van de Arbeidsvoorzieningsorganisatie?

Globaal gesproken is voor de bovengenoemde drie gebruiksdoelen van de Arbeidsmarktvoorzieningsorganisatie behoefte aan twee soorten informatie:

- actuele arbeidsmarktinformatie als basis voor een monitoringsysteem van arbeidsmarktontwikkelingen;

- $\quad$ middellange en korte-termijn prognoses van de verwachte arbeidsmarktontwikkelingen.

Zowel voor het monitoringsysteem als voor het prognosesysteem van het RAIS is een drietal invalshoeken van cruciaal belang, te weten:

- bedrijfssectorinformatie;

- beroepeninformatie;

- opleidingeninformatie.

Het RAIS zal daarbij de ontwikkelingen aan zowel de vraag- als de aanbodzijde van de arbeidsmarkt in beeld moeten brengen, met een uiteindelijke toespitsing op het monitoren en prognosticeren van de discrepanties tussen vraag en aanbod. Dit betekent dat in dit rapport niet expliciet zal worden ingegaan op de beleidsinformatie met betrekking tot de marktpositie die de

4. Bij de meeste van deze databronnen is het gezien de aard van de data of de te geringe steekproefomvang, niet mogelijk op regionaal niveau te verbijzonderen naar sector, beroep of opleiding. 
$-3-$

Arbeidsvoorzieningsorganisatie op de verschillende deelmarkten inneemt. Aangenomen mag worden dat regionaal onderzoek in het kader van de beide landelijke grootschalige onderzoeken op dit terrein 'Hoe werven bedrijven' (Arbeidsvoorziening, 1993A) en 'Hoe zoeken werkzoekenden' (Arbeidsvoorziening, 1993B) op dit punt adequate beleidsinformatie kunnen genereren.

De verdere opzet van dit rapport is als volgt. Eerst zal in hoofdstuk 2 in antwoord op de eerste onderzoekvraag een overzicht worden gegeven van de relevante beschikbare informatiebronnen. Daarna zal in hoofdstuk 3 worden ingegaan op de mogelijkheden die er zijn om deze informatiebronnen te combineren tot voor de Arbeidsvoorzieningsorganisatie relevante beleidsinformatie. Daarbij wordt ook ingegaan op de mogelijkheden om op basis van de beschikbare informatiebronnen arbeidsmarktprognoses op te stellen. Bovendien wordt aandacht besteed aan de mogelijkheden die het combineren van deze externe arbeidsmarktinformatie met de intern beschikbare (PGI) informatie biedt. Tenslotte zullen in hoofdstuk 4 de contouren worden geschetst van een mogelijk regionaal arbeidsmarktinformatiesysteem ten behoeve van de Arbeidsvoorzieningsorganisatie. 


\section{BESCHIKBARE REGIONALE INFORMATIEBRONNEN}

In dit hoofdstuk zal in het kort worden uiteengezet welke arbeidsmarktinformatie de belangrijkste momenteel beschikbare informatiebronnen bevatten. Daarbij staan telkens de drie in de inleiding genoemde invalshoeken, die voor de gebruiksbehoeften van het RBA van cruciaal belang zijn, centraal: bedrijfssectorinformatie, beroepeninformatie en opleidingeninformatie. Achtereenvolgens zal worden ingegaan op de Enquête Regionale Bedrijfsontwikkeling van de Kamers van Koophandel, het Vestigingenregister Limburg van het ETIL en de beide Limburgse RBA's, de Enquête Beroepsbevolking van het CBS, het informatiesysteem onderwijs-arbeidsmarkt van het ROA, de RUBS-schoolverlaters enquête van het RDC, het Servicebureau Schoolverlatersinformatie en het ROA en het Bedrijfsinformatiesysteem (BIS) van het GMD.

\section{Enquête Regionale Bedrijfsontwikkeling (ERBO)}

De jaarlijkse ERBO-enquête van de gezamenlijke Kamers van Koophandel en Fabrieken geeft voor de provincie Limburg arbeidsmarktinformatie, verbijzonderd naar 29 branches c.q. 19 bedrijfssectoren. Tevens wordt de informatie verbijzonderd naar de vier Kamer van Koophandeldistricten in Limburg: Maastricht en Omstreken, de Mijnstreek, Midden Limburg en Noord Limburg. De twee eerstgenoemde districten omvatten gezamenlijk de RBA-regio Zuid Limburg, terwijl de laatste twee districten corresponderen met de RBA-regio Midden- en Noord-Limburg.

De arbeidsmarktinformatie van de ERBO-enquête beperkt zich tot de totale werkgelegenheidsontwikkeling per bedrijfssector (verbijzonderd naar bedrijven met minder dan 50 werkzame personen en bedrijven met 50 of meer werkenden), de door de ondernemers verwachte werkgelegenheidsontwikkeling voor het komende jaar en informatie over het al dan niet bestaan van knelpunten ten aanzien van opleiding/scholing en vacaturevervulling. Tabel 2.1 geeft een illustratie van deze arbeidsmarktinformatie met betrekking tot de horecasector.

Tabel 2.1 Werkgelegenheid en werkgelegenheidsverwachtingen horecasector volgens ERBO-enquête Limburg

$\begin{array}{lll}\text { Maastricht } \quad \text { Mijnstreek } & \begin{array}{l}\text { Midden- } \\ \text { Limburg }\end{array} & \begin{array}{l}\text { Noord- } \\ \text { Limburg }\end{array}\end{array}$

Werkgelegenheidsontwikkeling

1991 t.o.v. 1990

Werkgelegenheidsverwachtingen

1992 t.o.v. 1991

(\% bedrijven)

$\begin{array}{lcc} & +5 \% & -1 \% \\ \text { Afname } & 3 & 3 \\ \text { Gelijk } & 86 & 91 \\ \text { Toename } & 11 & 6\end{array}$

$\begin{array}{cc}-2 \% & +1 \% \\ 2 & 1 \\ 93 & 92 \\ 4 & 7\end{array}$

Bron: Kamers van Koophandel

De arbeidsmarktinformatie heeft alleen betrekking op het bedrijfsleven. Echter, niet alleen de gehele (semi)overheidssector, maar ook een deel van de landbouwsector en de zelfstandige 
beroepsbeoefenaren blijven buiten beschouwing. Naast de werkgelegenheidsinformatie wordt er indicatieve informatie verstrekt over de omzet, export, bedrijfsresultaten en investeringen naar bedrijfssector. De gehanteerde bedrijfsindeling correspondeert met de Standaard Bedrijfsindeling (SBI) van het CBS.

In de ERBO-enquête van de Limburgse Kamers van Koophandel wordt ook gevraagd of de 'vervulling van vacatures een knelpunt is of een bijzonder aandachtspunt voor het komende jaar'. In aansluiting daarop is in 1992 voor het eerst gevraagd naar het aantal openstaande vacatures en het voor deze vacatures vereiste opleidingsniveau. Deze vacaturecijfers zijn verbijzonderd naar functiecategorie. De daarbij gehanteerde beroepenindeling correspondeert met de beroepenindeling die gehanteerd wordt in het PGI-systeem van de Arbeidsvoorzieningsorganisatie. Vooralsnog is het nog onzeker of deze vacaturevraag ook de komende jaren aan de ERBO-enquête zal worden toegevoegd.

\section{Vestigingenregister Limburg}

Het ETIL beheert in een samenwerkingsverband met de beide RBA's in Limburg het 'Vestigingenregister Limburg'. Toen het Landelijk Informatiesysteem Arbeidsorganisaties (LISA) nog bestond, werd daarmee samengewerkt. In het kader van het Vestigingenregister wordt jaarlijks een enquête gehouden onder bedrijven en instellingen in Limburg. Vanaf 1988 zijn er jaarlijks gegevens beschikbaar over de werkgelegenheidsomvang, verbijzonderd naar geslacht en omvang van de werkweek (meer of minder dan 15 uur per week) ${ }^{5}$. De gegevens zijn bovendien op een laag aggregatieniveau te verbijzonderen naar regio (codering op postcode) en bedrijfsgroep (SBI-4 digit) ${ }^{6}$ In 1991 zijn tevens eenmalig de intra- en interregionale forensenstromen in kaart gebracht. Ten opzichte van de eerder genoemde ERBO-enquête heeft het Vestigingenregister als voordeel dat de werkgelegenheidsinformatie niet alleen betrekking heeft op het bedrijfsleven, maar op alle economische activiteiten, waaronder de (semi-)overheid. Bovendien verschaft het Register informatie over het niveau van de werkgelegenheid en daarmee van de sectorale werkgelegenheidsstructuur in de beide Limburgse RBA-regio's. Vanwege de beperkte steekproefomvang en de jaarlijkse verbeteringen van het bestand moet de werkgelegenheidsontwikkeling van jaar op jaar op gedetailleerd niveau met enige voorzichtigheid geïnterpreteerd worden.

\section{Enquête Beroepsbevolking}

$\mathrm{Na}$ de laatste volkstelling van 1971, is er door het CBS in de periode 1975-1985 tweejaarlijks een Arbeidskrachtentelling gehouden. In 1987 is deze Arbeidskrachtentelling opgevolgd door een doorlopende maandelijkse enquête, de Enquête Beroepsbevolking (EBB). Uit de EBB kunnen

5. Eerdere waarnemingsjaren betreffen 1973, 1977 en 1983.

6. Overigens bevat de Statistiek Werkzame Personen van het CBS soortgelijke informatie op een hoger aggregatieniveau. 
in principe arbeidsmarktgegevens naar bedrijfssector ${ }^{7}$, beroep en opleiding worden verkregen op zowel provinciaal als RBA-niveau. Doordat het CBS alleen bij een aantal werkenden van minimaal 5000 in een bepaalde sector, beroep of opleiding gegevens wil publiceren, is met name de informatie beperkt die op RBA-niveau kan worden gegenereerd.

Uit een verkennende analyse van Berendsen cs. (1992) bleek dat door deze publicatierestrictie voor de provincie Limburg slechts voor 31 van de 88 (ROA)beroepsklassen de werkgelegenheid(sontwikkeling) in beeld kan worden gebracht. (Zie tabel 2.2$)^{8}$.

Tabel 2.2. Werkgelegenheid(sontwikkeling) in de belangrijkste beroepsklassen in Limburg, gemiddelde 1988-1990

ROA- Beroepsklasse
$\begin{aligned} & \text { Aantal } \\ & \text { code }\end{aligned}$

0131 Leerkrachten basis- en speciaal onderwijs

0132 Docenten voortgezet en hoger onderwijs

werkenden

2011 Uitvoerend agrarisch personeel, bosarbeiders

$\begin{aligned} 7.000 & \text { dalend } \\ 11.000 & \text { constant } \\ 13.000 & \text { constant } \\ 11.000 & \text { dalend } \\ 27.000 & \text { stijgend } \\ 7.000 & \text { dalend } \\ 6.000 & \text { constant } \\ 5.000 & \text { dalend } \\ 7.000 & \text { stijgend } \\ 6.000 & \text { dalend } \\ 8.000 & \text { constant } \\ 7.000 & \text { stijgend } \\ 8.000 & \text { stijgend } \\ 14.000 & \text { dalend } \\ 9.000 & \text { constant } \\ 8.000 & \text { stijgend } \\ 5.000 & \text { stijgend } \\ 9.000 & \text { constant } \\ 24.000 & \text { constant } \\ 25.000 & \text { constant } \\ 5.000 & \text { constant } \\ 29.000 & \text { constant } \\ 11.000 & \text { dalend } \\ 6.000 & \text { dalend } \\ 13.000 & \text { constant } \\ 6.000 & \text { dalend } \\ 20.000 & \text { constant } \\ 13.000 & \text { stijgend } \\ & \end{aligned}$

2012 Zelfstandige agrariërs, boswachters

3021 Directeuren, bedrijfsleiders, leidinggevenden industrie

3312 Houtbewerkers, timmerlieden

3612 Machinale metaalbewerkers

3613 Lassers, constructiewerkers, edelmetaalsmeden

3614 Machinebank- en plaatwerkers, gereedschaps- en modelmakers

3615

3721

Onderhoudsmonteurs, fietsen- en instrumentmakers

4011 Laders, lossers, vul- en inpak (machine) bedienden

4211 Conducteurs, chauffeurs e.a. transportmiddelenbestuurders

5021 Gediplomeerde verpleegkundigen, verloskundigen

5022 Leerling-verpleegkundigen, zieken- en kraamverzorgenden

6031 Hogere leidinggevenden

6122 Secretaressen, typisten

6124 Boekhoudkundigen, belasting-, loket- en bankemployees

6125 Commercieel-administratieve employees

6126 Telefonisten, balie-employees, enquêteurs e.d.

6211 Winkel-, straat- en marktverkopers, demonstrateurs

6221 Winkeliers e.a. detail- en groothandelaren

6222 In-/verkoopchefs, handels- en verzekeringsagenten, makelaars e.d.

8111 Koks, kelners e.a. keuken- en serveerpersoneel

8121 Houders en leidinggevenden horeca- en recreatiebedrijven

8211 Portiers, schoonmaak- e.a. lager dienstverlenend personeel

455.000

rend

8212 Kinder-, gezins-, bejaardenverzorgenden e.a. verzorgend personeel

Bron: CBS/ROA

7. De bedrijfssectorcijfers zullen hier niet verder worden uitgewerkt.

8. De tabellen 2.2-2.5 hebben betrekking op de EBB-informatie met betrekking tot Limburg, zoals die momenteel bij het ROA aanwezig is. In principe is het mogelijk om de arbeidsmarktinformatie voor een bepaald kalenderjaar in de eerste helft van het daarop volgende jaar beschikbaar te krijgen. 
Overigens gaat het bij deze 31 beroepsklassen in totaal om $74 \%$ van de totale werkgelegenheid in Limburg. Voor de RBA's Midden en Noord Limburg en Zuid Limburg kan de werkgelegenheidsontwikkeling slechts worden getraceerd voor respectievelijk 14 en 13 beroepsklassen; respectievelijk 53 en $49 \%$ van de totale werkgelegenheid in het desbetreffende RBA-gebied (zie tabel 2.3A en 2.3B).

Tabel 2.3A. Werkgelegenheid(sontwikkeling) in de belangrijkste beroepsklassen in de RBA-regio Middenen Noord-Limburg, gemiddelde 1988-1990

\begin{tabular}{|c|c|c|c|}
\hline $\begin{array}{l}\text { ROA- } \\
\text { code }\end{array}$ & Beroepsklasse & $\begin{array}{l}\text { Aantal } \\
\text { werkenden }\end{array}$ & Trend \\
\hline 2011 & Uitvoerend agrarisch personeel, bosarbeiders & 10.000 & stijgend \\
\hline 2012 & Zelfstandige agrariërs, boswachters & 8.000 & constant \\
\hline 3021 & Directeuren, bedrijfsleiders, leidinggevenden industrie & 13.000 & sterk stijgend \\
\hline 4011 & Laders, lossers, vul- en inpak (machine)bedienden & 6.000 & stijgend \\
\hline 4211 & Conducteurs, chauffeurs e.a. transportmiddelenbestuurders & 7.000 & dalend \\
\hline 5022 & Leerling-verpleegkundigen, zieken- en kraamverzorgenden & 5.000 & dalend \\
\hline 6124 & Boekhoudkundigen, belasting-, loket en bankemployees & 11.000 & constant \\
\hline 6125 & Commercieel-administratieve employees & 10.000 & stijgend \\
\hline 6211 & Winkel-, straat- en marktverkopers, demonstrateurs & 12.000 & stijgend \\
\hline 6221 & Winkeliers e.a. detail- en groothandelaren & 5.000 & dalend \\
\hline 8111 & Koks, kelners e.a. keuken- en serveerpersoneel & 5.000 & constant \\
\hline 8211 & Portiers, schoonmaak- e.a. lager dienstverlenend personeel & 9.000 & stijgend \\
\hline 8212 & $\begin{array}{l}\text { Kinder-, gezins-, bejaardenverzorgenden e.a. verzorgend } \\
\text { personeel }\end{array}$ & 5.000 & constant \\
\hline & Totaal (incl. beroep onbekend) & 200.000 & \\
\hline
\end{tabular}

Bron: CBS/ROA

Tabel 2.3B. Werkgelegenheid(sontwikkeling) in de belangrijkste beroepsklassen in de RBA-regio ZuidLimburg, gemiddelde 1988-1990

\begin{tabular}{|c|c|c|c|}
\hline $\begin{array}{l}\text { ROA } \\
\text { code }\end{array}$ & Beroepsklasse & $\begin{array}{l}\text { Aantal } \\
\text { werkenden }\end{array}$ & Trend \\
\hline 0132 & Docenten voortgezet hoger onderwijs & 7.000 & dalend \\
\hline 3021 & Directeuren, bedrijfsleiders, leidinggevenden industrie & 16.000 & constant \\
\hline 4211 & Conducteurs, chauffeurs e.a. transportmiddelenbestuurders & 8.000 & stijgend \\
\hline 5022 & Leerling-verpleegkundigen, zieken- en kraamverzorgenden & 5.000 & constant \\
\hline 6124 & Boekhoudkundigen, belasting-, loket- en bankemployees & 14.000 & dalend \\
\hline 6125 & Commercieel-administratieve employees & 16.000 & dalend \\
\hline 6211 & Winkel-, straat- en marktverkopers, demonstrateurs & 16.000 & stijgend \\
\hline 6221 & Winkeliers e.a. detail- en groothandelaren & 7.000 & dalend \\
\hline 8111 & Koks, kelners e.a. keuken- en serveerpersoneel & 7.000 & constant \\
\hline 8211 & Portiers, schoonmaak- e.a. lager dienstverlenend personeel & 12.000 & constant \\
\hline \multirow[t]{2}{*}{8212} & $\begin{array}{l}\text { Kinder-, gezins-, bejaardenverzorgenden e.a. verzorgend } \\
\text { personeel }\end{array}$ & 9.000 & stijgend \\
\hline & Totaal (incl. beroep onbekend) & 254.000 & \\
\hline
\end{tabular}


$-8-$

Bij een onderscheid naar opleidingstype was het mogelijk om voor 12 van de 20 door het ROA onderscheiden opleidingstypen op AVO, LBO of MBO-niveau (zie tabel 2.4) informatie te geven over de omvang van de werkgelegenheid. ${ }^{9}$ Voor de regio's RBA Midden- en Noord Limburg en RBA-Zuid Limburg kan voor respectievelijk 11 en 10 opleidingstypen de werkgelegenheid in kaart worden gebracht (zie tabel 2.5).

Tabel 2.4. Werkgelegenheid naar opleidingstype in Limburg, 1990

\begin{tabular}{llr}
$\begin{array}{l}\text { SOI- } \\
\text { code }\end{array}$ & Naam opleiding & \multicolumn{1}{c}{$\begin{array}{l}\text { Aantal } \\
\text { werkenden }\end{array}$} \\
\hline 000, 111,201 & Basisonderwijs & 54.000 \\
301 & MAVO en onderbouw HAVO/VWO & 39.000 \\
$321-329$ & LBO Agrarisch & 7.000 \\
$331-339$ & LBO Technisch & 43.000 \\
$361-369$ & LBO Economisch-Administratief & 10.000 \\
$381-389$ & LBO Verzorgend & 26.000 \\
401 & Bovenbouw HAVO/VWO & 22.000 \\
$421-429$ & MBO Agrarisch & 9.000 \\
$436-439$ & MBO Technisch & 51.000 \\
451,454 & MBO Verpleging \& Ziekenverzorging & 15.000 \\
$453,461-464$ & MBO Economisch \& Administratief & 52.000 \\
$481,484,486$ & MBO Verzorgend & 20.000 \\
\hline
\end{tabular}

Bron: CBS/ROA

Tabel 2.5. Werkgelegenheid naar opleidingstype in de regio's RBA Midden- en Noord-Limburg en RBA Zuid-Limburg, 1990

\begin{tabular}{|c|c|c|}
\hline SOI- & Naam opleiding & Aantal werkenden \\
\hline code & & $\begin{array}{ll}\text { Midden- en } & \text { Zuid- } \\
\text { Noord-Limburg } & \text { Limburg }\end{array}$ \\
\hline
\end{tabular}

\begin{tabular}{llrr}
\hline & & & \\
$000,111,201$ & Basisonderwijs & 23.000 & 30.000 \\
301 & MAVO en onderbouw HAVO/VWO & 16.000 & 22.000 \\
$321-329$ & LBO Agrarisch & 5.000 & 22.000 \\
$331-339$ & LBO Technisch & 20.000 & 6.000 \\
$361-369$ & LBO Economisch-Administratief & 12.000 & 14.000 \\
$381-389$ & LBO Verzorgend & 9.000 & 12.000 \\
401 & Bovenbouw HAVO/VWO & 7.000 & 29.000 \\
$421-429$ & MBO Agrarisch & 21.000 & 10.000 \\
$436-439$ & MBO Technisch & 5.000 & 28.000 \\
451,454 & MBO Verpleging \& Ziekenverzorging & 23.000 & 10.000 \\
$453,461-464$ & MBO Economisch Administratief & 10.000 & \\
$481,484,486$ & MBO Verzorgend & & \\
\hline
\end{tabular}

Bron: CBS/ROA

9. Opleidingstypen op HBO- en WO-niveau zijn in het onderzoek van Berendsen cs. (1992) buiten beschouwing gebleven. 
Recentelijk heeft het CBS aangegeven dat, wanneer er gebruik gemaakt zou worden van een driejaars gemiddelde, de werkgelegenheidscijfers reeds gepubliceerd mogen worden bij een ondergrens van 2000 personen. Aangenomen mag worden dat bij deze lagere ondergrens voor aanmerkelijk meer bedrijfssectoren, beroepsklassen en opleidingstypen de werkgelegenheidsontwikkeling in beeld kan worden gebracht, dan bij de tot op heden gehanteerde ondergrens van 5000 eenheden.

Tenslotte mag niet onvermeld blijven dat de EBB-informatie in principe ook verbijzonderd kan worden naar geslacht, leeftijd en etnische groep. Bovendien kan informatie worden gegenereerd over pendelstromen naar sector, beroep en opleiding (zie Hoevenberg cs. 1993). Vanwege de bovengenoemde door het CBS gestelde ondergrenzen voor publikatie van EBB-gegevens, zal deze informatie slechts beschikbaar kunnen komen op een hoog aggregatieniveau.

\section{ROA-informatiesysteem onderwijs en arbeidsmarkt}

Het vanaf 1987 door het ROA ontwikkelde informatiesysteem onderwijs-arbeidsmarkt verschaft informatie over de actuele en toekomstige arbeidsmarktpositie, toegespitst op de discrepantie tussen vraag en aanbod op de arbeidsmarkt naar beroep en opleiding. In concreto gaat het daarbij om prognoses van de werkgelegenheidsontwikkeling (de 'uitbreidingsvraag'), de vervangingsvraag en de instroom van nieuwkomers op de arbeidsmarkt. Momenteel heeft deze informatie betrekking op 93 beroepsklassen en 49 opleidingstypen, waarvoor eind 1993 nieuwe landelijke prognoses zullen worden verstrekt voor de periode 1993-1998. Daarnaast levert het informatiesysteem ook actuele arbeidsmarktinformatie voor 54 bedrijfsklassen en bevat het de arbeidsmarktprognoses van het Centraal Planbureau voor 17 bedrijfssectoren. De daarbij gehanteerde indelingen zijn volledig koppelbaar met de bestaande CBS-classificaties.

Zoals hieronder wordt aangegeven, is het mogelijk soortgelijke arbeidsmarktinformatie te genereren op provincie- en RBA-niveau, waarbij de arbeidsmarktprognoses naar beroepsklassen en opleidingstypen voortbouwen op de regionale prognoses van de werkgelegenheid naar bedrijfssector van het Centraal Bureau van de Arbeidsvoorzieningsorganisatie. Tabel 2.6 geeft een tweetal voorbeelden van de ROA-arbeidsmarktprognoses voor de provincie Limburg (zie Berendsen cs. 1992).

Recentelijk zijn de regionale bedrijfssectorprognoses van het CBA voor het eerst verbijzonderd naar RBA-regio (Natzijl en Westra, 1993). In principe is het ook mogelijk deze prognoses op basis van de ROA-methodiek te verbijzonderen naar beroepsklassen en opleidingstypen. Het aantal beroepsklassen en opleidingstypen waarvoor dergelijke gegevens zouden kunnen worden gepresenteerd zal echter kleiner zijn dan het aantal categorieën dat op provincieniveau kan worden onderscheiden. Voor de verschillende opleidingstypen kunnen deze vraagprognoses worden geconfronteerd met prognoses van de te verwachten instroom van schoolverlaters op de arbeidsmarkt, mede met behulp van onderwijsuitstroom prognoses van INRO-TNO (Buist en Vermeulen, 1992). De daarbij te volgen aanpak wordt beschreven in Berendsen cs. (1992). 
Tabel 2.6. Voorbeeld van ROA-arbeidsmarktprognoses naar beroep en opleiding voor de provincie Limburg, 1989-1994

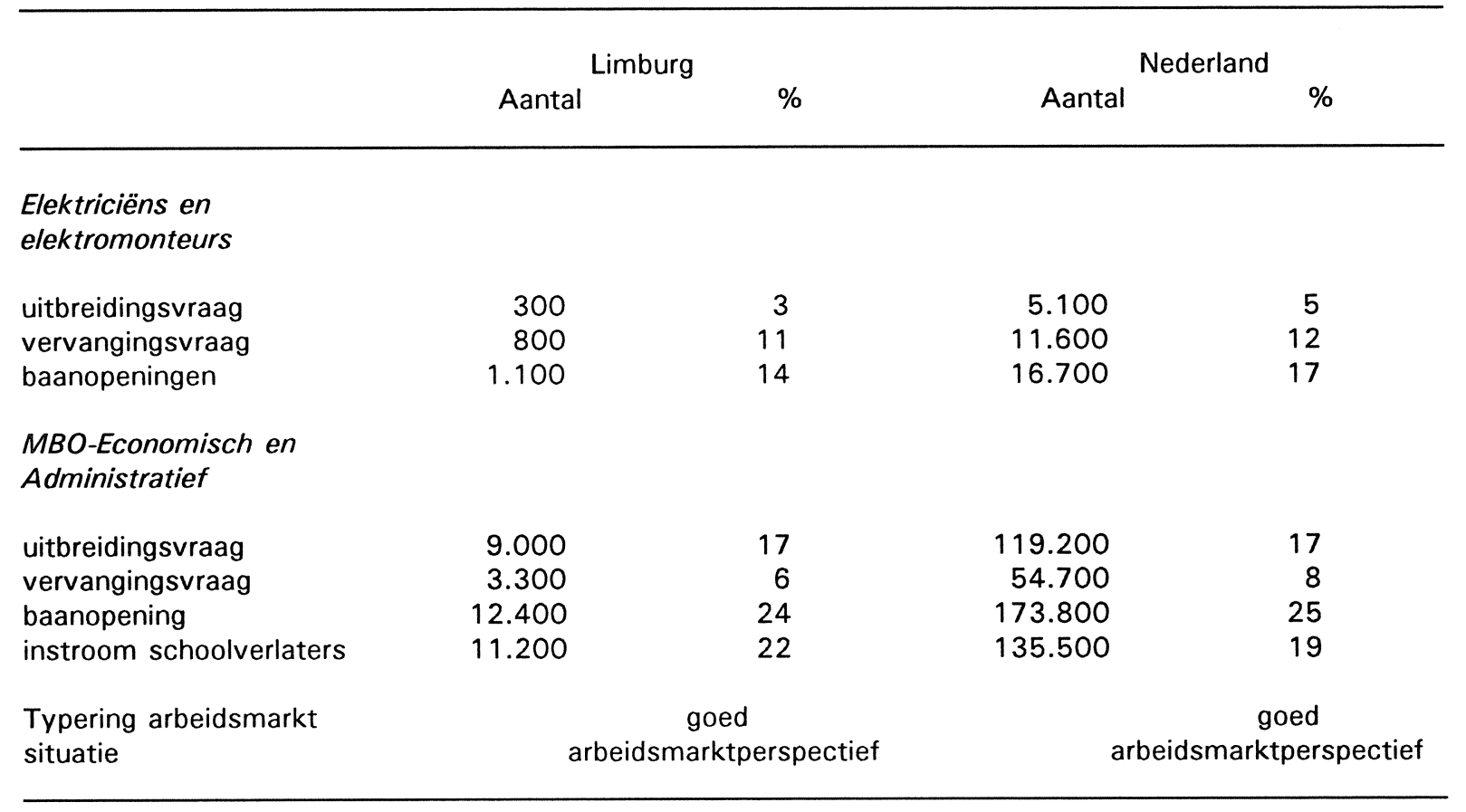

Bron: ROA (Berendsen cs. 1992)

Naast de genoemde prognoses, verschaft het ROA-informatiesysteem ook informatie over de actuele arbeidsmarktsituatie, zoals deze gekarakteriseerd kan worden door het werkloosheidspercentage, en de trendmatige ontwikkeling daarvan. De werkloosheid naar opleidingstype is tot voor kort door het ROA in beeld gebracht door het bemiddelingsbestand zonder baan (BZB) van de Arbeidsvoorzieningsorganisatie te relateren aan het aantal werkenden met de desbetreffende opleidingsachtergrond volgens de EBB. Deze koppeling van de werkloosheidsdata van de arbeidsvoorzieningsorganisatie aan de EBB-data is in principe ook mogelijk op RBA-niveau.

Wieling cs. (1991) presenteren een maatstaf voor de regionale werkloosheid onder de schoolverlaters op RBA-niveau door de werkloze schoolverlaters volgens het BZB te relateren aan het aantal schoolverlaters met de desbetreffende opleidingsachtergrond. Dit laatste gegeven is afkomstig uit het Regionalisering Uitstroom Voortgezet Onderwijs (RUVO-) project van INROTNO (zie Vermeulen, 1990). Tabel 2.7 geeft een overzicht van de aldus bepaalde werkloosheidspercentages onder schoolverlaters voor de beide Limburgse RBA-gebieden.

Daarnaast wordt in het ROA-informatiesysteem onderwijs en arbeidsmarkt op basis van de EBB ook informatie verschaft over de belangrijkste bedrijfsklassen en beroepsklassen waar een bepaalde opleidingscategorie werkzaam is. Tevens kan worden aangegeven welke beroepsklassen binnen een bepaalde bedrijfsklasse het belangrijkst zijn. 
Tabel 2.7. Werkloosheidspercentage schoolverlaters per opleidingstype in de RBA-regio's Midden- en Noord-Limburg en Zuid Limburg, april 1991

\begin{tabular}{lccc}
\hline Opleidingstype & $\begin{array}{c}\text { RBA } \\
\text { Midden- } n \\
\text { Noord-Limburg } \\
\%\end{array}$ & $\begin{array}{c}\text { RBA } \\
\text { Zuid-Limburg }\end{array}$ & Nederland \\
& $\%$ & $\%$ \\
\hline & & & 32 \\
MAVO, onderbouw HAVO/VWO & 23 & 90 & 9 \\
LBO Agrarisch & 23 & 32 & 44 \\
LBO Technisch & 4 & 16 & 24 \\
LBO Economisch-Administratief & 50 & 36 & 20 \\
LBO Verzorgend & 20 & 34 & 3 \\
Bovenbouw HAVO/VWO & 22 & 69 & 8 \\
MBO Agrarisch & 2 & 5 & 4 \\
MBO Technisch & 8 & 30 & 9 \\
MBO Medisch Laboratorium & 0 & 1 & 10 \\
MBO Verpleging \& Ziekenverzorging & 5 & 12 & 12 \\
MBO Economisch-Administratief & 6 & 14 & 4 \\
MBO Bestuurlijk & 4 & 30 & 5 \\
MBO Sociaal-Cultureel & 6 & 40 & \\
MBO Verzorging & 7 & 19 & \\
\hline
\end{tabular}

Bron: CBS/CBA/INRO-TNO/ROA

\section{RUBS-Schoolverlatersenquête}

De Registratie Uitstroom en Bestemming van Schoolverlaters (RUBS) enquête, die wordt uitgevoerd door een samenwerkingsverband van de RDC's, het Servicebureau Schoolverlatersinformatie en het ROA, genereert zeer specifieke informatie over de eerste bestemming op de arbeidsmarkt van schoolverlaters uit het algemeen voortgezet onderwijs en het lager en middelbaar beroepsonderwijs ${ }^{10}$. Een groot aantal aspecten van de aansluitingsproblematiek kunnen daarbij worden belicht: de doorstroom naar vervolgopleidingen, de relatieve omvang van de werkloosheid, de bedrijfsgroep en het beroep waarin men werk vindt, de doorstroom naar het leerlingwezen of in-service opleidingen, de wijze waarop men aan de baan is gekomen, de zoektijd en zoekkanalen, de beloning, de eventuele aanvullende scholing die men volgt en de 'kwalitatieve aansluitingsproblemen' tussen de gevolgde opleiding en de functie die men uitoefent. (zie Wieling cs. 1993)

In 1992 is voor de eerste keer een 'romp-enquête' uitgevoerd over de volle breedte van het algemeen voortgezet onderwijs en het lager en middelbaar beroepsonderwijs, op basis waarvan op landelijk niveau representatieve arbeidsmarktinformatie kan worden verschaft. Deze enquête heeft betrekking op de schoolverlaters van het schooljaar 1990-1991. RDC-Limburg rapporteert in drie afzonderlijke publicaties over de bestemming van de AVO/VWO/LBO en (K)MBO-

10. Door het ROA wordt soortgelijke informatie gegenereerd over HBO-afgestudeerden op basis van de HBO-monitor, en over afgestudeerden van de Rijksuniversiteit Limburg, op basis van de Arbeidsmarktscanner RL. 
schoolverlaters in de provincie Limburg (zie RDC-Limburg 1993 A,B en C). In principe is de RUBS-informatie beschikbaar op een zeer laag aggregatieniveau, zowel naar bedrijfssubgroep (SBI-4 digit) en beroep (CBS-4 digit) als naar opleiding (RUBS-6 digit) ${ }^{11}$. Dankzij de grote steekproefomvang en de relatief hoge respons ${ }^{12}$, kunnen met behulp van de RUBS-enquête op relatief lage aggregatie-niveaus voor veel studierichtingen waardevolle indicaties worden verkregen van de relatie tussen opleiding en beroep en de andere eerder genoemde aspecten van de aansluitingsproblematiek tussen onderwijs en arbeidsmarkt. ${ }^{13}$ De met behulp van de RUBS-enquête gegenereerde informatie kan ook worden uitgesplitst naar leeftijd, geslacht en etnische groep.

\section{Bedrijfsinformatiesysteem GMD}

Vanaf 1989 is in de GMD regio's Venlo en Maastricht/Heerlen een BedrijfsInformatiesysteem (BIS) operationeel. Het BIS is gebaseerd op een schriftelijke vragenlijst die wordt voorgelegd aan werkgevers op het moment dat een werknemer bij de GMD wordt aangemeld. De respons op deze enquête is vrij hoog. Daarbij wordt informatie verkregen over in principe alle in de organisatie aanwezige functies, het aantal mensen dat in de verschillende functies werkzaam is, de voor een bepaalde functie vereiste opleiding bij indiensttreding en het salaris. Tevens wordt gevraagd naar het aantal in dienst zijnde werknemers met een AAW/WAO uitkering.

Door de koppeling van het BIS aan het Functie Informatiesysteem van de GMD dat gerelateerd is aan de CBS-classificaties, is ook de BIS-informatie zowel naar bedrijf als beroep koppelbaar aan de bestaande CBS-codes. Bovendien kan op deze wijze de aard van de functie worden getypeerd naar inhoud, niveau, werkbelasting en werkomstandigheden.

Gezien de wijze waarop de dataverzameling is georganiseerd, kan op basis van het BIS geen informatie worden verkregen over werkgelegenheidsontwikkelingen. Wel kan een tamelijk verfijnd beeld worden verkregen van de beroepenstructuur van de werkgelegenheid in Limburg naar bedrijfssector, verbijzonderd naar de beide RBA regio's. Bovendien kan daarbij inzicht worden verkregen in de bovengenoemde specifieke kenmerken van de beroepen die in de verschillende sectoren voorkomen. Vanwege de huidige reorganisatie bij de GMD is het echter op dit moment onduidelijk in hoeverre het BIS in de toekomst zal worden gecontinueerd. ${ }^{14}$

11. Deze indeling is koppelbaar aan de Standaard Onderwijs Indeling van het CBS.

12. In totaal bevat het RUBS-1992 bestand informatie over 7700 schoolverlaters in de provincie Limburg, waarvan ruim 3800 hun opleiding volgden in Noord- en Midden Limburg en circa 3900 in Zuid Limburg.

13. Indien gebruik wordt gemaakt van meerjaarlijkse gemiddelden zijn nog verdergaande verbijzonderingen mogelijk.

14. Met name in de GMD-regio Venlo lijkt het BIS momenteel reeds dood te bloeden. 


\section{BELEIDSRELEVANTE ARBEIDSMARKTINFORMATIE}

\subsection{Inleiding}

Zoals in de inleiding van het rapport reeds werd opgemerkt, staat bij het beantwoorden van de vraag in hoeverre er mogelijkheden bestaan om op basis van de beschikbare informatie beleidsrelevante arbeidsmarktinformatie te genereren, een drietal beleidsdoeleinden van de Arbeidsvoorzieningsorganisatie centraal, te weten:

- het Regionaal Meerjaren Beleidsplan;

- de scholingsplanning;

- het bemiddelingsbeleid.

In dit hoofdstuk zal nader op de bovenstaande vraag worden ingegaan. Daarbij zal ook zijdelings aandacht worden besteed aan de gebruikswaarde van de arbeidsmarktinformatie voor het (studie- en beroepskeuze)voorlichtingsbeleid. Globaal gesproken heeft het gebruik van externe arbeidsmarktinformatie voor de Arbeidsvoorzieningsorganisatie als belangrijk voordeel dat niet louter hoeft te worden afgegaan op de arbeidsmarktinformatie waarover men intern beschikt. Deze interne informatie kan immers sterk zijn gekleurd door de eigen positie op de verschillende deelmarkten.

Alvorens nader in te gaan op de wijze waarop de beschikbare arbeidsmarktinformatie, en de op basis daarvan op te stellen arbeidsmarktprognoses, specifiek zouden kunnen worden afgestemd op de bovengenoemde gebruiksdoelen, zal eerst meer in het algemeen worden ingegaan op de mogelijkheden om op basis van de in het vorige hoofdstuk beschreven beschikbare (externe) arbeidsmarktinformatie, in combinatie met de intern beschikbare PGI-informatie, te komen tot voor de Regionale Arbeidsvoorzieningsorganisatie beleidsrelevante arbeidsmarktinformatie. Daarbij komt ook de koppelingsproblematiek tussen de externe en interne informatie aan de orde.

\subsection{Combinatiemogelijkheden en koppelingsproblemen}

Schema 3.1 geeft een totaaloverzicht van de beschikbare relevante externe en interne arbeidsmarktinformatie naar sector, beroep en opleiding. 
Schema 3.1. Beschikbare arbeidsmarktinformatie naar bedrijf, beroep en opleiding

\begin{tabular}{llll}
\hline Informatiebron & Bedrijf & Beroep & Opleiding
\end{tabular}

Monitoring
ERBO
Vestigingenregister
Limburg
Enquête Beroepsbevol-
king

werkgelegenheidsontwikkeling (alleen bedrijfsleven)

werkgelegenheids-

ontwikkeling

- naar geslacht

werkgelegenheidsont-

wikkeling

- naar geslacht, leeftijd

en etnische groep

- pendelstromen

ROA-informatiesysteem

arbeidsmarktindicatoren op basis van

Enquête Beroeps-

bevolking

RUBS-

schoolverlatersenquête

Instroom schoolverlaters in diverse sectoren

\section{vacatures}

(incidenteel)

idem

idem

idem

vereiste opleidingsniveau voor vacatures (incidenteel) instroom schoolverlaters in diverse beroepen
Bedrijfsinformatiesysteem GMD

PGI

\author{
(moeilijk vervulbare) \\ vacatures \\ - aantal \\ - in- en uitstroom
}

werkgelegenheid

- beroepeninformatie naar niveau, werkbelasting en werkomstandigheden

werklozen (BZB)

- aantal

- in- en uitstroom werklozen (BZB)

- aantal en in- en uitstroom

- naar geslacht, leeftijd, nationaliteit en duur

- schoolverlatersinformatie

\section{Arbeidsmarktprog-} noses *

ROA-informatiesysteem
- uitbreidingsvraag (bron: CBA/OAV)
- vervangingsvraag
- baanopeningen
- uitbreidingsvraag
- vervangingsvraag
- baanopeningen
- uitbreidingsvraag
- vervangingsvraag
- baanopeningen
- instroom schoolverla- ters bron: INRO-TNO
- indicator toekomstige arbeidsmarktsituatie (excl. HBO, WO)

\footnotetext{
* De genoemde arbeidsmarktprognoses zijn op regionaal niveau weliswaar niet automatisch beschikbaar
} maar kunnen op basis van de aanwezige arbeidsmarktinformatie in principe worden gegenereerd. 
Uit het schema kan in het algemeen worden geconcludeerd dat er in principe op RBA-niveau verschillende mogelijkheden bestaan om beleidsrelevante informatie te genereren. Daarbij doet zich echter een tweetal problemen voor:

- veel van de arbeidsmarktinformatie naar beroep en opleiding heeft betrekking op een relatief hoog aggregatieniveau;

- de externe informatie die is gebaseerd op standaardclassificaties van het CBS, kan niet direct gerelateerd worden aan de beschikbare interne arbeidsmarktinformatie.

Wat het eerstgenoemde probleem betreft, dient uitdrukkelijk te worden opgemerkt dat dit probleem zich niet of vrijwel niet voordoet met betrekking tot de arbeidsmarktinformatie naar bedrijfssector. Met name het Vestigingenregister Limburg, in combinatie met de ERBO-enquête en de Statistiek Werkloze Personen, kan op dit punt de voor de verschillende gebruiksdoeleinden relevante arbeidsmarktinformatie genereren. Zeer interessant als monitoring-indicator is ook een recentelijk door INRO-TNO ontwikkelde indicator die op basis van een drietal gegevens, afkomstig uit de ERBO-enquête, de ontwikkelingen in de bedrijfsvitaliteit op een zeer laag aggregatieniveau in beeld brengt ${ }^{15}$.

In aanvulling daarop zou op basis van de EBB meer specifieke informatie kunnen worden verkregen ten behoeve van het doelgroepenbeleid, door de beschikbare verbijzonderingen naar geslacht, leeftijd en etnische groep. Deze laatste informatie kan, zoals in het vorige hoofdstuk werd aangegeven, echter alleen verkregen worden wanneer het gaat om minimaal 5.000 personen. Door uit te gaan van driejaarsgemiddelden kan deze ondergrens verschoven worden naar 2000 personen. Uitgaande van dezelfde ondergrenzen genereert het ROA-informatiesysteem per bedrijfstak de belangrijkste beroepsklassen en opleidingstypen, alsmede indicatoren met betrekking tot de conjunctuurgevoeligheid van de werkgelegenheid.

Informatie over de verwachte toekomstige arbeidsmarktontwikkelingen naar bedrijfssector kan worden verkregen op basis van de regionale werkgelegenheidsprognoses die het CBA voornemens is dit jaar op RBA-niveau te publiceren. In principe is het mogelijk om deze 'uitbreidingsvraagprognoses' aan te vullen met ROA-prognoses van de vervangingsvraag naar bedrijfssector.

De belangrijkste informatiebron voor het in beeld brengen van de regionale werkgelegenheid naar beroep en opleiding is de EBB. Vanwege de eerder genoemde ondergrenzen voor publikatie van deze gegevens kan op RBA-niveau, zoals gezegd, slechts een beperkt aantal globale beroeps- en opleidingscategorieën worden onderscheiden. Meer specifieke informatie is vooralsnog alleen beschikbaar op basis van de RUBS-schoolverlatersenquête. Op deze wijze kan op een relatief laag aggregatieniveau een beeld verkregen worden van de belangrijkste beroepen waar schoolverlaters uit het voortgezet onderwijs instromen ${ }^{16}$. Bovendien geeft deze school-

15. Deze indicator is gebaseerd op de reële ontwikkeling van de omzet, de bedrijfsresultaten en de investeringen per bedrijfsvestiging (zie Tordoir, cs. 1993).

16. Zoals in het vorige hoofdstuk werd aangegeven is er soortgelijke informatie beschikbaar voor de $\mathrm{HBO}$-afgestudeerden en de afgestudeerden van de Rijksuniversiteit Limburg. 
verlatersenquête, met name verbijzonderd naar opleiding, een schat aan informatie met betrekking tot de directe aansluiting tussen het initiële onderwijs en de eerste bestemming op de arbeidsmarkt.

Met betrekking tot de afstemming van vraag en aanbod op de regionale arbeidsmarkt, verbijzonderd naar opleiding en beroep, vormt de PGI-informatie van de Arbeidsvoorzieningsorganisatie zelf de meest gedetailleerde informatie die er beschikbaar is. Op basis van de beschikbare gegevens kan echter alleen een beeld worden verkregen van het absolute aantal werklozen en vacatures, de ontwikkelingen daarin en de werkloosheids- en vacatureduur. Nog afgezien van de registratieproblemen die zich bij zowel de vacature- als de werkloosheidscijfers voordoen, geven deze absolute aantallen werklozen en vacatures geen goed beeld van de spanning op een bepaald arbeidsmarktsegment. Wel kan een werkloosheids-vacature ratio ('UV-ratio', zie bv. De Grip, 1987) een eerste indruk geven van de situatie op de arbeidsmarkt. Dit kan echter alleen met een verbijzondering naar beroepsgroep.

Voor het meer accuraat in beeld brengen van de arbeidsmarktsituatie naar sector, beroep en opleiding is het gewenst de vacature- en/of werkloosheidscijfers te relateren aan de omvang van de beroepsbevolking of de werkzame bevolking op het desbetreffende arbeidsmarktsegment. Een voorbeeld hiervan is het door Berendsen cs. (1992-I) gegenereerde werkloosheidspercentage per opleidingstype, waarbij het BZB-bestand gerelateerd is aan het aantal werkenden met de desbetreffende opleidingsachtergrond volgens de EBB. Op soortgelijke wijze zouden ook de geregistreerde vacaturecijfers naar beroepsgroep en sector gerelateerd kunnen worden aan het aantal werkenden op het desbetreffende arbeidsmarktsegment.

Een probleem hierbij is de bovengenoemde beperkte koppelbaarheid tussen de door de Arbeidsvoorzieningsorganisatie gehanteerde classificaties en de CBS-classificaties die ten grondslag liggen aan de genoemde externe informatiebronnen. In het verleden zijn zowel door de centrale Arbeidsvoorzieningsorganisatie als door het ROA schakelschema's opgesteld die het mogelijk maken de beroepen (ARBI) en opleidingen (AROI) classificaties van Arbeidsvoorziening te relateren aan de desbetreffende CBS-classificaties. Temeer daar het CBS recentelijk een nieuwe beroepenclassificatie heeft ontwikkeld, die in aanzienlijke mate meer arbeidsmarktrelevant is dan de huidige CBS-beroepenclassificatie, zou het zeer wenselijk zijn om op korte termijn na te gaan in hoeverre de momenteel door de Arbeidsvoorzieningsorganisatie gehanteerde 'functie-informatie typering' (FIT) aan deze nieuwe 'Standaard Beroepenclassificatie' van het CBS gerelateerd kan worden. Het ontwikkelen van een dergelijk schakelschema heeft als voordeel dat gebruik gemaakt kan worden van de informatie met betrekking tot diverse functievereisten, waaronder het vereiste opleidingsniveau, die impliciet besloten ligt in de nieuwe CBS-beroepencodes (zie Bakker cs., 1993).

Op soortgelijke wijze zou in de toekomst getracht moeten worden schakelschema's te ontwikkelen tussen de door Arbeidsvoorziening gehanteerde opleidingsclassificatie en de nieuwe opleidingenclassificatie die het CBS momenteel voorbereidt. Daarop vooruitlopend zou kunnen worden nagegaan in hoeverre de in zeer vergaande mate verbijzonderde opleidingenclassificatie 
zoals die in de RUBS-enquête wordt gehanteerd, gerelateerd kan worden aan de opleidingsindeling van Arbeidsvoorziening.

\subsection{Beleidsrelevantie voor de verschillende gebruiksdoelen}

Hoewel voor alle drie genoemde gebruiksdoelen van de Arbeidsvoorzieningsorganisatie in principe behoefte is aan arbeidsmarktinformatie naar sector, beroep en opleiding, zou met name voor het Regionaal Meerjaren Beleidsplan en het bemiddelingsbeleid de arbeidsmarktinformatie verbijzonderd naar bedrijfssector een centrale plaats kunnen innemen. Dit zou het mogelijk maken de te stellen beleidsdoelen op basis van de beschikbare arbeidsmarktprognoses te verbijzonderen naar bedrijfssector, alsmede deze doelstellingen ook op sectorniveau te evalueren op basis van de beschikbare monitoring-informatie. Voor het bemiddelingsbeleid zou de arbeidsmarktinformatie verbijzonderd naar bedrijfssector als leidraad kunnen gelden bij het vaststellen van het marktconforme capaciteitsbeslag dat een bepaalde bedrijfssector zou dienen te krijgen. Tevens kan de sectorale arbeidsmarktinformatie zeer waardevol zijn voor het opstellen van sectorale convenanten tussen de Arbeidsvoorzieningsorganisatie en de sociale partners.

\section{Regionaal Meerjaren Beleidsplan}

Figuur 3.1 geeft een beeld van de wijze waarop deze bedrijfssectorinformatie gegenereerd zou kunnen worden ten behoeve van het Regionaal Meerjaren Beleidsplan. ${ }^{17}$ Daarbij gaat het om een prognose van de werkgelegenheidsontwikkeling over een periode van circa 5 jaar (de 'uitbreidingsvraag'), aangevuld met de ROA-vervangingsvraagprognoses, in combinatie met enkele relevante indicatoren met betrekking tot het doelgroepenbeleid en indien mogelijk ook gecombineerd met de beschikbare PGI-informatie. Vanwege het middellange-termijn karakter van de prognoses is het niet wenselijk de sectorinformatie op een lager aggregatieniveau te genereren dan de 10 in de CBA-prognoses onderscheiden bedrijfssectoren. Dit relatief hoge aggregatieniveau vergemakkelijkt bovendien het verkrijgen van arbeidsmarktinformatie ten behoeve van het doelgroepenbeleid. De actuele werkgelegenheidsgegevens naar geslacht, leeftijd en etnische groep en de beschikbare PGI-informatie zouden vervolgens ook een rol kunnen spelen bij de beleidsevaluatie.

17. Ook zouden de relevante kengetallen kunnen worden opgenomen in het geplande bestuurlijk informatiesysteem en/of management informatiesysteem van het RBA. 
Figuur 3.1. Relevante arbeidsmarktinformatie voor het Regionaal Meerjaren Beleidsplan (naar bedrijfssector)
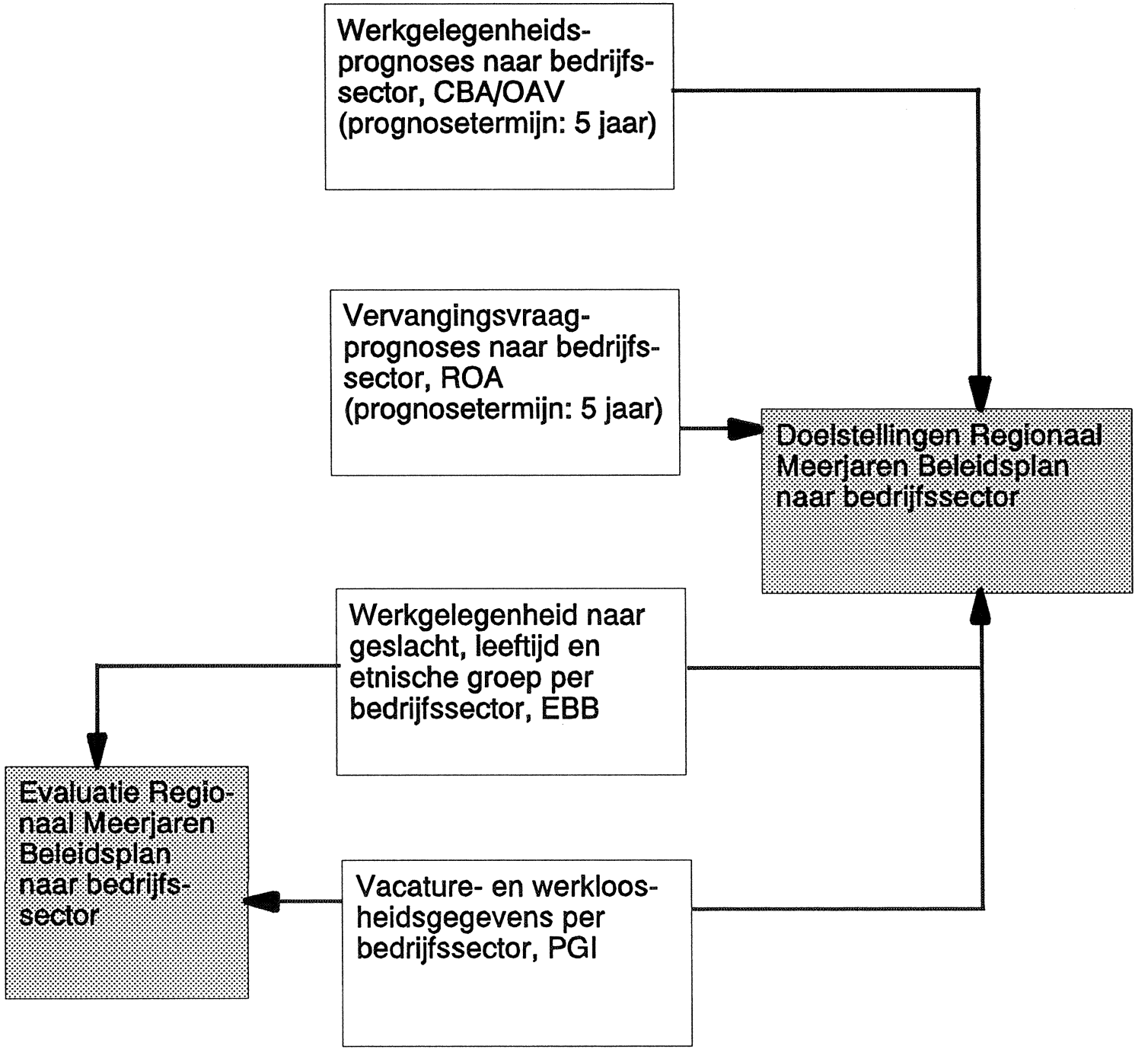

Indien gewenst kan de in figuur 3.1 aangegeven informatie worden aangevuld met soortgelijke arbeidsmarktinformatie naar beroepssector en opleidingscategorie. Voor het verbijzonderen van de beleidsdoelstellingen naar beroeps- en opleidingscategorie zou gebruik gemaakt kunnen worden van de regionale arbeidsmarktprognoses van het ROA. Actuele arbeidsmarktgegevens op hetzelfde hoge aggregatieniveau afkomstig uit de EBB, aangevuld met de beschikbare PGIinformatie bieden de mogelijkheid meer specifieke beleidsdoelen te formuleren en kunnen ook een rol spelen bij de beleidsevaluatie. Figuur 3.2 geeft een overzicht van deze mogelijke uitbreidingen van de arbeidsmarktinformatie ten behoeve van het Regionaal Meerjaren Beleidsplan. 
Figuur 3.2. Relevante arbeidsmarktinformatie voor het Regionaal Meerjaren Beleidsplan: uitbreiding naar beroep en opleiding

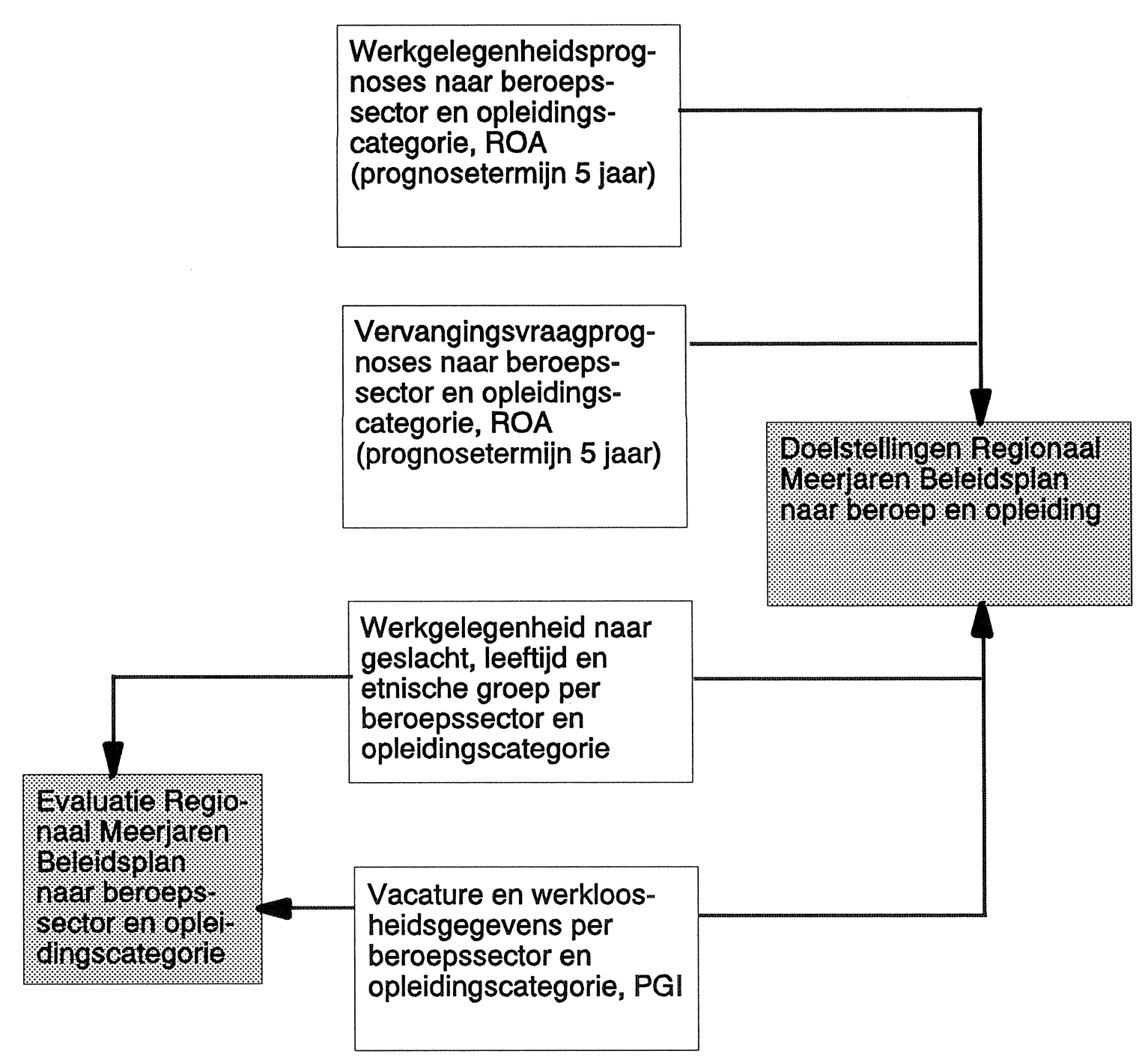

\section{Bemiddelingsbeleid}

Figuur 3.3 schetst de gewenste informatiestromen ten behoeve van het bemiddelingsbeleid. Ook hier wordt, zoals reeds werd aangegeven, geopteerd voor een sectorale invalshoek. De uitbreidingsvraagprognoses per bedrijfssector worden op dezelfde wijze verkregen als in figuur 3.1. werd aangegeven. Bij het bemiddelingsbeleid gaat de voorkeur echter uit naar korte-termijn prognoses, waarin circa een jaar vooruit wordt geblikt (zie ook Nieuwland en De Grip, 1993). Ook voor deze korte-termijn prognoses kunnen de werkgelegenheidsprognoses van het CBA als uitgangspunt dienen (zie Natzijl en Westra, 1993) ${ }^{18}$. Het korte-termijn karakter van de prognoses maakt het bovendien mogelijk om tegemoet te komen aan de wenselijkheid van arbeids-

18. Eventueel zou daarbij ook rekening kunnen worden gehouden met de verwachtingen op basis van meer recente macro-economische korte-termijn prognoses van het Centraal Planbureau. 
marktinformatie op een lager aggregatieniveau. Deze verbijzondering naar maximaal 54 bedrijfsklassen (eventueel aangevuld met globale indicatoren van de werkgelegenheidsontwikkeling naar bedrijfsgroep; of SBI 3-digit) kan in principe worden gerealiseerd met behulp van het Vestigingenregister Limburg en/of de ERBO-enquête, eventueel aangevuld met de op deze laatste informatiebron gebaseerde door INRO-TNO ontwikkelde vitaliteitsindex naar bedrijfsgroep (zie paragraaf 3.2).

Deze uitbreidingsvraagprognose naar bedrijfsklasse kan vervolgens weer worden aangevuld met ROA-prognoses van de vervangingsvraag naar bedrijfsklasse. Het aantal baanopeningen naar bedrijfsklasse (uitbreidingsvraag + vervangingsvraag) dat dan wordt verkregen, kan als maatstaf worden gehanteerd voor het vaststellen van het marktconforme capaciteitsbes/ag dat een bepaalde bedrijfsklasse binnen het bemiddelingsbeleid dient te krijgen. Dit marktconforme capaciteitsbeslag zou als ijkpunt kunnen fungeren met betrekking tot de marktpositie van de Arbeidsvoorzieningsorganisatie op de verschillende arbeidsmarktsegmenten.

Op basis van een zeer eenvoudige prognosemethodiek zou vervolgens indicatieve informatie kunnen worden gegenereerd met betrekking tot de beroepsklassen waarop de verwachte baanopeningen per bedrijfsklasse betrekking hebben en de voor deze functies vereiste opleiding. Het meer globale beeld dat in het ROA-informatiesysteem kan worden verkregen van de relatie opleiding-beroep zou met behulp van de RUBS-informatie over de relatie opleiding-beroep bij schoolverlaters mogelijk verder kunnen worden verbijzonderd. Daarbij kunnen op basis van de beschikbare RUBS-informatie ook indicaties worden gegeven van de mogelijke kwalitatieve aansluitingsproblemen die zich daarbij voordoen.

De aldus verkregen informatie kan als richtinggevend worden beschouwd voor de vacaturewerving en in combinatie met de gegevens met betrekking tot de werkzoekenden laten zien voor welke combinaties van opleiding en beroep de beste bemiddelingskansen mogen worden verwacht en welke bedrijfsklassen daarbij de beste intredeperspectieven bieden. Aangenomen mag worden dat de geregistreerde vacatures de eerste invalshoek blijven voor het bemiddelingsbeleid. Echter, op basis van de gegenereerde externe arbeidsmarktinformatie, kan de werkzoekende in aanvulling daarop ook gewezen worden op de bedrijfsklassen waar zich naar verwachting (nog meer) niet geregistreerde vacatures voordoen. Een dergelijke informatieverstrekking zal de 'indirecte bemiddeling' derhalve in belangrijke mate kunnen verbeteren. Dit zal de betekenis van de Arbeidsvoorzieningsorganisatie voor werkzoekenden aanzienlijk kunnen vergroten ${ }^{19}$, hetgeen ongetwijfeld op termijn de marktpositie van Arbeidsvoorziening ten goede zal komen.

19. Uit het 'Hoe zoeken werkzoekenden' onderzoek blijkt immers dat werkzoekenden het arbeidsbureau veel belangrijker vinden als bron van informatie, advies en kansvergroting, dan als directe bron van vacatures (zie Schouten en Van der Zwaan, 1993). 
Figuur 3.3. Relevante arbeidsmarktinformatie voor het bemiddelingsbeleid

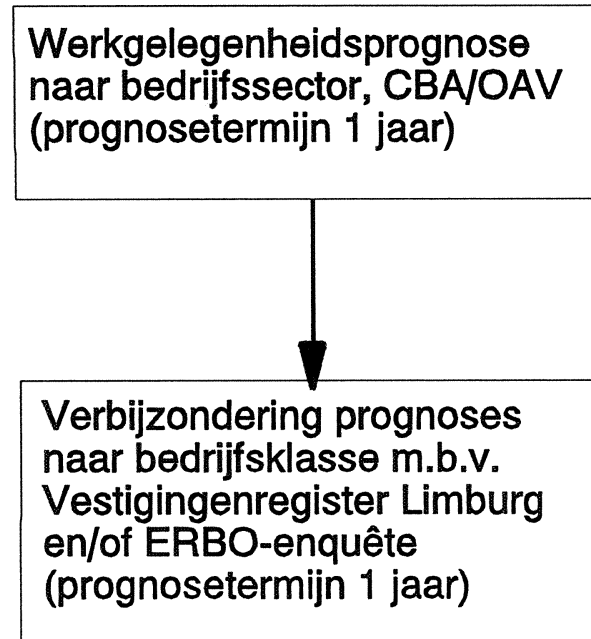

Werkgelegenheidsprognose naar bedriffssector, CBA/OAV (prognosetermijn 1 jaar)

Verbijzondering prognoses naar bedrijfsklasse m.b.v. en/of ERBO-enquête (prognosetermijn 1 jaar)

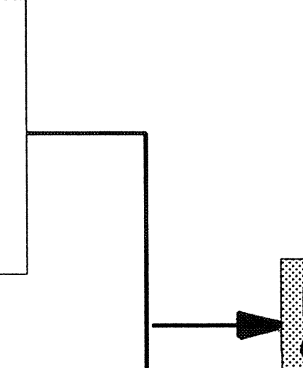

Marktcontorme capaciteitsbestac per bediffsklasse

Vervangingsvraagprognoses naar bedrijfsklasse, ROA (prognosetermijn 1 jaar)

Verbijzondering prognoses baanopeningen naar beroepsklasse en vereiste opleiding, ROA en RUBS

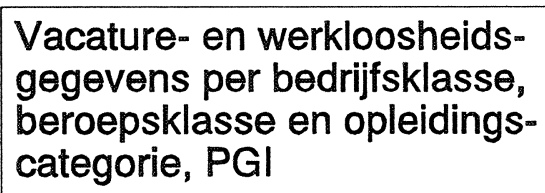




\section{Scholingsbeleid}

Figuur 3.4 geeft een overzicht van de informatiebronnen die relevant zijn voor het scholingsbeleid. Uitgangspunt daarbij zijn de bovengenoemde door het ROA gegenereerde prognoses van het aantal baanopeningen naar beroepsklasse of beroepssegment. Vanwege de relatief korte opleidingsduur van veel scholingstrajecten geniet een prognosetermijn van circa 1 jaar daarbij de voorkeur. Deze prognosetermijn sluit ook goed aan bij de in de Kaderwet Volwasseneneducatie van 1991 aan de RBA's met ingang van het jaar 1994 opgelegde verplichting om jaarlijks een Regionaal Scholingsplan vast te stellen, waarin een analyse van de regionale scholingsbehoeften moet worden opgesteld.

Naast deze vraagprognoses zouden vervolgens prognoses moeten worden opgesteld van de te verwachten instroom van schoolverlaters. INRO-TNO heeft reeds eerder dergelijke prognoses opgesteld naar opleidingscategorie (Vermeulen, 1990). Nagegaan zou moeten worden op welke wijze dergelijke prognoses getransformeerd zouden kunnen worden naar beroepsklasse of beroepssegment en/of indicatoren kunnen worden ontwikkeld met betrekking tot het recruteringspotentieel voor de verschillende beroepsklassen. De ROA-prognosemethodiek biedt daarvoor in principe aanknopingspunten. Confrontatie van deze vraag- en aanbodprognoses naar beroepsklasse geeft een indicatie van de verwachte knelpunten op de arbeidsmarkt waarop het scholingsbeleid van de Arbeidsvoorzieningsorganisatie zou kunnen inspelen. Deze prognoses zouden daarbij kunnen worden afgezet en/of verder kunnen worden verbijzonderd op basis van (ontwikkelingstendensen in) de geregistreerde vacaturecijfers. Vanzelfsprekend dient bij een dergelijke vraag-aanbod confrontatie ook rekening te worden gehouden met de te verwachten pendelstromen. Op basis van de EBB en de RUBS-schoolverlatersenquête zouden daarvoor indicatoren kunnen worden opgesteld, verbijzonderd naar beroep en/of opleiding (zie ook Hoevenberg cs., 1993).

Op basis van met name de RUBS-schoolverlatersenquêtes en eventuele bestemmingsenquêtes van de cursisten van bepaalde scholingstrajecten kan vervolgens een beeld worden geschetst van de voor deze knelpuntberoepen feitelijk geldende opleidingsvereisten. Deze in principe op zeer laag aggregatieniveau te genereren informatie zou richtinggevend kunnen zijn voor de capaciteitsplanning van het scholingsbeleid in het algemeen en de te initierren her-, om- of bijscholing in het bijzonder ${ }^{20}$. Overigens zou het op dit punt waarschijnlijk ook zeer waardevol kunnen zijn om in aanvulling op de gegenereerde data, op basis van een aantal gesprekken met sleutelpersonen uit het bedrijfsleven tot een nog verdere toespitsing van de gesignaleerde scholingsbehoeften te komen.

Een bij voorkeur continue c.q. periodieke evaluatie van het interne en externe rendement van de reeds bestaande cursussen en vakopleidingen ${ }^{21}$ zou vervolgens in samenhang met het gefor-

20. Overigens zou de RUBS-enquête ook informatie kunnen genereren over de bijscholingsbehoefte van kwetsbare groepen schoolverlaters, die slechts werkzaam zijn in een tijdelijk dienstverband.

21. Een dergelijke evaluatie past ook binnen de aan de RBA's opgelegde taakstelling met betrekking tot het opstellen van een Regionaal Scholingsplan. 
muleerde doelgroepenbeleid, een belangrijke basis kunnen vormen voor de selectie van de werkzoekenden die bij voorkeur voor een bepaald scholingstraject in aanmerking dienen te komen. Daarbij dient er voor te worden gezorgd dat de bij dit evaluatie-onderzoek gehanteerde classificaties naar sector, beroep en opleiding koppelbaar zijn met de desbetreffende Standaardclassificaties van het CBS.

Figuur 3.4. Relevante arbeidsmarktinformatie voor het scholingsbeleid

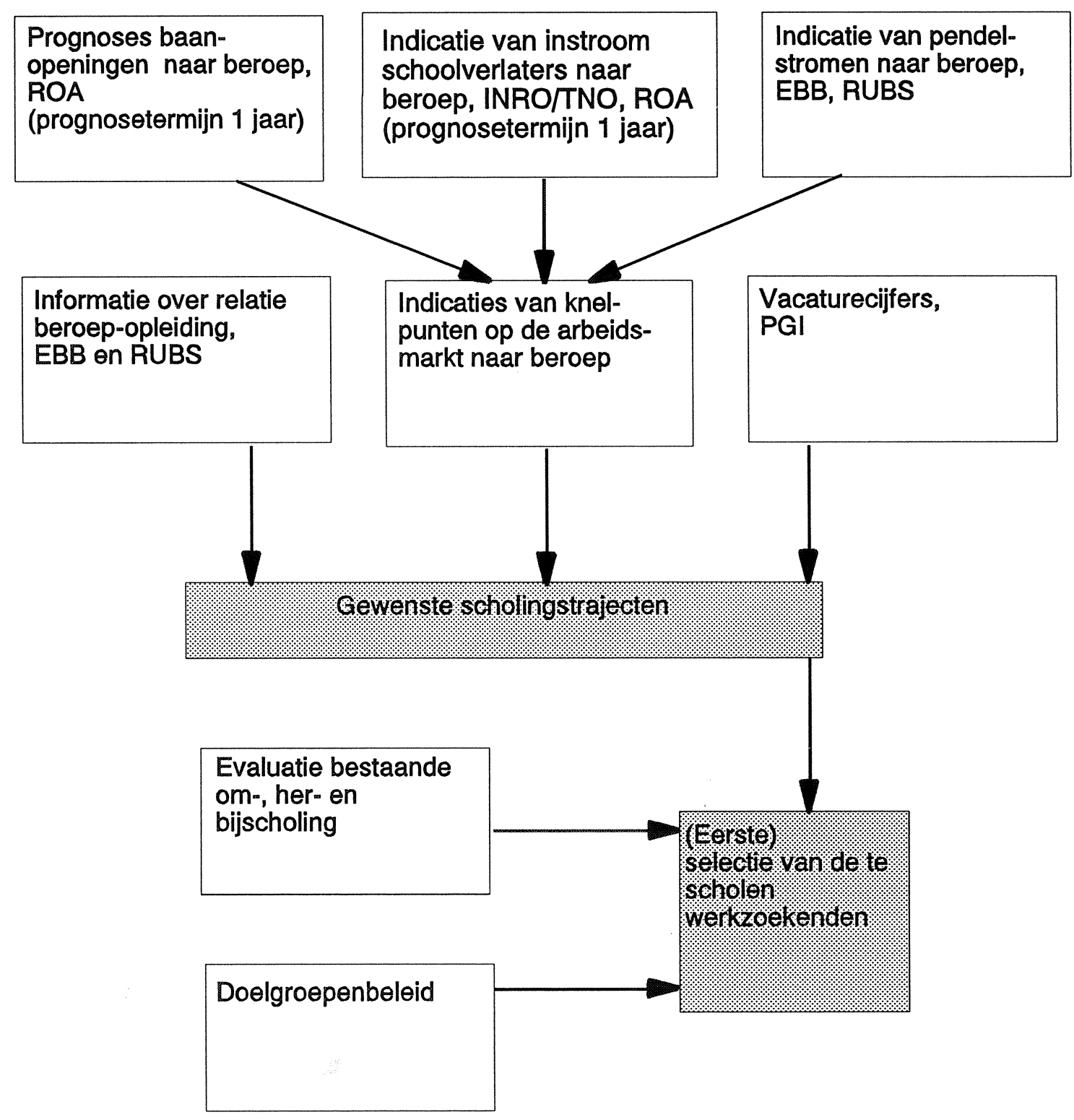




\section{CONTOUREN RAIS}

In het vorige hoofdstuk is een beeld geschetst van de mogelijkheden om op basis van de momenteel beschikbare c.q. te genereren arbeidsmarktinformatie te komen tot beleidsrelevante informatie ten behoeve van de regionale Arbeidsvoorzieningsorganisatie. Daarbij kunnen vrijwel alle in hoofdstuk 2 beschreven informatiebronnen een waardevolle rol spelen. De enige uitzondering is wat dit betreft de beroepeninformatie waarover de GMD beschikt. De onzekerheid over de (wijze van) voortzetting van dit Bedrijfsinformatiesysteem, alsmede de enigszins arbitraire wijze waarop de gegevensverzameling tot stand komt, maken de GMD-informatie vooralsnog minder geschikt om op te nemen in een Regionaal Arbeidsmarkt Informatie-systeem (RAIS).

Een belangrijk voordeel van deze externe arbeidsmarktinformatie boven de interne PGI-informatie is, nog afgezien van de 'vervuilingsproblematiek' van de Arbeidsvoorzieningsdata, dat op deze wijze een evenwichtig beeld kan worden gegeven van de actuele arbeidsmarktsituatie, ontwikkelingstrends en toekomstverwachtingen over de volle breedte van de arbeidsmarkt, zonder dat dit beeld vertekend wordt door de marktpositie van de Arbeidsvoorzieningsorganisatie op een bepaald arbeidsmarktsegment. Desalniettemin kan de betekenis van de externe arbeidsmarktinformatie van de Arbeidsvoorzieningsorganisatie worden vergroot door het mogelijk te maken deze informatie te combineren met de intern beschikbare vacature- en werkloosheidscijfers. Dit vereist het ontwikkelen van adequate schakelschema's tussen:

1. De beroepenclassificatie zoals die tot stand komt op basis van het FIT-systeem en de nieuwe Standaard Beroepen Classificatie '92 van het CBS.

2. De AROI opleidingenclassificatie en de (vernieuwde) Standaard Onderwijs Indeling van het CBS en/of de RUBS-opleidingenclassificatie.

Bovendien heeft het prognosticeren van verwachte arbeidsmarktontwikkelingen op basis van enerzijds de werkgelegenheids- en vervangingsvraagontwikkeling en anderzijds de instroom van nieuwkomers een groot voordeel boven het voorspellen van arbeidsmarktontwikkelingen op basis van vacaturecijfers. In de eerste plaats omdat ontwikkelingen in vacaturecijfers als gevolg van kettingreactiemechanismen een sterk vertekend beeld kunnen geven van de ontwikkeling van de feitelijke baanopeningen op de arbeidsmarkt (zie De Grip, c.s., 1993). In de tweede plaats is het extrapoleren van vacaturegegevens een zeer hachelijke zaak vanwege het 'saldo'karakter (vraag naar arbeid - werkzame bevolking) van deze cijfers. De ontwikkeling van de vacaturecijfers in de jaren ' 80 spreekt wat dit betreft boekdelen (Wegerif, 1992).

De grote betekenis die de externe arbeidsmarktinformatie voor het regionale arbeidsmarktbeleid in principe kan hebben, neemt niet weg dat op enkele punten eerst meer concreet zal moeten worden nagegaan met welke mate van detail bepaalde informatie daadwerkelijk kan worden gegenereerd. Dit geldt met name voor de verbijzondering van de EBB-data naar geslacht, leeftijd en etnische groep. Ook het transformeren van de sterk geaggregeerde bedrijfssectorprognoses van het CBA tot verder verbijzonderde bedrijfsklasseprognoses met behulp van de beschikbare informatie uit het Vestigingenregister Limburg en/of de ERBO-enquête dient in een pilot-studie 
nader te worden onderzocht. Hetzelfde geldt voor het verbijzonderen van deze prognoses naar beroepsklasse en vereiste opleiding. Temeer indien daarbij getracht zou worden op basis van de RUBS-informatie tot in vergaande mate gedesaggregeerde opleidingeninformatie te komen (zie figuur 3.3). Ook de in figuur 3.4 geschetste aanpak om te komen tot relevante arbeidsmarktinformatie ten behoeve van het scholingsbeleid zal eerst in een pilot-studie moeten worden geconcretiseerd om na te gaan op welke wijze de mogelijke uitvoeringsproblemen, die daarbij kunnen optreden, zouden kunnen worden opgelost.

Desalniettemin geven de figuren 3.1-3.4 duidelijk de contouren aan van een RAIS dat ontwikkeld zou kunnen worden ten behoeve van de Arbeidsvoorzieningsorganisatie. Daarbij wordt telkens langs een tweetal lijnen verbetering gebracht in de beschikbare interne arbeidsmarktinformatie, waarmee momenteel binnen de Arbeidsvoorzieningsorganisatie wordt gewerkt. In de eerste plaats maken de CBA-OAV prognoses in combinatie met de door het ROA recentelijk ontwikkelde regionale beroepen- en opleidingprognoses het mogelijk om op basis van een 'topdown' aanpak te komen tot, op landelijk niveau consistente, regionale arbeidsmarktprognoses naar bedrijfssector, beroepsklasse en opleidingstype (zie Berendsen cs., 1992). Een aanvullende 'bottom-up' aanpak, op basis van informatie afkomstig uit de ERBO-enquête, het Vestigingenregister Limburg, de RUBS-schoolverlatersenquête en de intern beschikbare PGI-informatie, biedt vervolgens mogelijkheden om (1) deze arbeidsmarktinformatie verder te verbijzonderen, (2) de actuele ontwikkelingen te monitoren en (3) de gestelde beleidsdoelen te evalueren.

Een primair op de gebruiksdoelen van de Arbeidsvoorzieningsorganisatie afgestemd RAIS kan ook gezien worden als een belangrijke eerste stap in de richting van een voor meerdere doelgroepen, waaronder het bedrijfsleven, relevant RAIS-Limburg. Het is echter op voorhand niet duidelijk of op basis van de in dit rapport beschreven arbeidsmarktinformatie een dergelijk multi-functioneel RAIS op adequate wijze zou kunnen worden ingevuld. Ten aanzien van de implementatie van een op de Arbeidsvoorzieningsorganisatie afgestemd RAIS kunnen verschillende wegen worden gevolgd. Globaal gesproken staan daarbij een al dan niet stapsgewijze aanpak over de volle breedte van het informatiesysteem en een stapsgewijze aanpak met betrekking tot de drie beleidsdoelen tegenover elkaar. In het laatste geval ligt het voor de hand om in eerste instantie te werken aan een RAIS ten behoeve van het Regionaal Meerjaren Beleidsplan.

Samengevat vereist het concretiseren van het RAIS de volgende activiteiten:

1. Concreet nagaan welke informatie de EBB op RBA-niveau kan opleveren naar bedrijf, beroep, opleiding, geslacht, leeftijd en etnische groep.

2. Pilot-studie met betrekking tot de arbeidsmarktprognoses die relevant zijn voor het Regionaal Meerjaren Beleidsplan (zie figuur 3.1).

3. Ontwikkelen van schakelschema's tussen enerzijds de beroepen- en opleidingsclassificaties van Arbeidsvoorziening en anderzijds de Standaard classificaties van het CBS.

4. Pilot-studies concretisering RAIS met betrekking tot:

- het Regionaal Meerjaren Beleidsplan (zie figuur 3.1 en 3.2);

- bemiddelingsbeleid (zie figuur 3.3); 
- scholingsbeleid (zie figuur 3.4).

5. Evaluatiestudies met betrekking tot het interne- en externe rendement scholingsactiviteiten Arbeidsvoorziening.

6. Organisatorische vormgeving dataverwerking en databeheer RAIS.

In aansluiting op het ten behoeve van de Arbeidsvoorzieningsorganisatie ontwikkelde RAIS, zou nagegaan kunnen worden in hoeverre het RAIS ook ten dienste zou kunnen komen van mogelijke andere gebruikersgroepen (bv. de provinciale overheid en het bedrijfsleven). In dat geval zullen in eerste instantie de volgende twee stappen moeten worden gezet:

7. Verkennen van de gewenste uitbreidingsmogelijkheden van het RAIS ten behoeve van andere gebruikersgroepen.

8. Nagaan van de wenselijkheid van eventuele additionele meetinstrumenten voor het genereren van aanvullende informatie.

Meer in concreto zou voor de verdere ontwikkeling van RAIS aan een viertal mogelijke vervolgtrajecten kunnen worden gedacht, waarbij het RAIS steeds verder zou kunnen worden uitgebouwd. Bovendien kan daarbij telkens ook een feitelijke invulling aan het informatiesysteem worden gegeven.

1. Regionale prognoses van de werkgelegenheidsontwikkeling en de vervangingsbehoefte naar bedrijfssector en beroepssegment op RBA-niveau

In aansluiting op de regionale prognoses van de werkgelegenheidsontwikkeling op middellange termijn van het Centraal Bureau voor de Arbeidsvoorziening en de landelijke arbeidsmarktprognoses van het ROA, kunnen op RBA-niveau prognoses worden opgesteld van het verwachte totale aantal baanopeningen (uitbreidingsvraag en vervangingsvraag) naar bedrijfssector en beroepsklasse voor de periode 1993-1998 ${ }^{22}$. Indien gewenst kan daarbij ook een indicatie worden gegeven van de verwachte vraagontwikkeling in het eerstkomende jaar.

Op deze wijze wordt concreet invulling gegeven aan de bovenste helft van de figuren 3.1$3.4^{23}$. Deze prognoses hebben een directe gebruikswaarde voor het formuleren van de doelstellingen van het Regionaal Meerjaren Beleidsplan naar bedrijfssector (zie figuur 3.1) en beroepssegment (zie figuur 3.2). Tevens zouden relevante kengetallen kunnen worden opgenomen in het geplande bestuurlijke informatiesysteem en/of management informatiesysteem van het RBA. Ook wordt reeds enige richtinggevende informatie verkregen voor het vaststellen van het 'marktconforme capaciteitsbeslag' voor het bemiddelingsbeleid (zie figuur 3.3) en het scholingsbeleid (zie figuur 3.4). Tevens zou uit de Enquête Beroepsbevolking van

22. Een dergelijke aanpak is reeds eerder gevolgd met betrekking tot de arbeidsmarkt in de provincie Noord-Holland (zie Berendsen cs., 1992-II).

23. Daarbij wordt nog geen invulling gegeven aan de verbijzondering van de prognoses naar bedrijfsklasse (op basis van het Vestigingenregister Limburg en/of de ERBO-enquête), de prognoses naar opleidingstype en de instroom van schoolverlaters (zie figuur 3.3 en 3.4). 
het CBS de informatie kunnen worden gegenereerd met betrekking tot de huidige werkgelegenheid naar geslacht, leeftijd en etnische groep per bedrijfssector en beroepssegment. Op basis van deze informatie kan worden aangegeven of de potentiële werkgelegenheid voor deze doelgroepen in de nabije toekomst naar verwachting toeneemt of krimpt. Bovendien maakt deze informatie een verdere invulling c.q. onderbouwing van de doelstellingen van het Regionaal Meerjaren Beleidsplan mogelijk (zie figuur 3.1 en 3.2).

Daar voor het opstellen van bovenstaande prognoses met name gebruik zal worden gemaakt van de EBB, bestaan er aanzienlijke schaalvoordelen indien de vraagprognoses voor alle RBA's (c.q. een groot aantal RBA-regio's) zouden worden opgesteld. In navolging van de landelijke arbeidsmarktprognoses zouden deze regionale prognoses om de twee jaar kunnen worden geactualiseerd.

II. Verbijzonderen werkgelegenheids- en vervangingsvraagprognoses naar bedrijfsklasse, beroep en opleiding en prognose instroom schoolverlaters

\section{A. Bedrijfsklassen}

Met behulp van de beschikbare regionale arbeidsmarktinformatie van het Vestigingenregister Limburg en/of de ERBO-enquête zouden de bovengenoemde prognoses verder kunnen worden verbijzonderd naar bedrijfsklasse. Daarbij zal worden uitgegaan van een prognosetermijn van 1 jaar. Dit maakt het mogelijk op een meer verfijnd niveau het 'marktconforme' capaciteitsbeslag van het bemiddelingsbeleid vast te stellen (zie figuur 3.3). Overigens kunnen met behulp van de verkregen informatie ook de doelstellingen van het Regionaal Meerjaren Beleidsplan op een lager aggregatieniveau worden geformuleerd.

\section{B. Beroep en opleiding}

In aansluiting op de landelijke arbeidsmarktprognoses van het ROA en de beschikbare regionale arbeidsmarktinformatie uit de RUBS-schoolverlatersenquête, zouden de ad I genoemde prognoses van de werkgelegenheidsontwikkeling en de vervangingsvraag ook verder kunnen worden verbijzonderd naar beroep en opleiding. Daarbij zal tevens een indicatie worden gegeven van de bedrijfsklassen waar de verwachte baanopeningen naar beroep en opleiding zich zullen voordoen. De opleidingsinformatie is van belang voor alle drie genoemde gebruiksdoelen (zie figuur 3.2-3.4). Door de baanopeningen naar beroep te confronteren met de prognoses van de instroom van schoolverlaters naar beroepsklasse en/of indicatoren met betrekking tot het recruteringspotentieel van de verschillende beroepsklassen, kunnen ook indicaties worden gegeven van de verwachte knelpunten op de arbeidsmarkt naar beroep, die in belangrijke mate richtinggevend kunnen zijn voor het scholingsbeleid. Daarbij zal ook een indicatie moeten worden gegeven van de te verwachten pendelstromen (zie figuur 3.4).

Gezien de aard van de ad II.A en II.B beschreven vervolgactiviteiten, waarbij met name ('bottom-up') regiospecifieke informatie dient te worden ingepast in de 'top-down' opgestelde 
arbeidsmarktprognoses, is er in eerste instantie slechts in beperkte mate sprake van schaalvoordelen bij een grootschalige aanpak voor meerdere RBA-regio's. Derhalve verdient een pilotstudie met betrekking tot de beide Limburgse RBA-regio's de voorkeur.

\section{Integreren vacature- en werkloosheidsgegevens PGI}

Het combineren van de eerder genoemde externe arbeidsmarktinformatie naar sector, beroep en opleiding met de vacature- en werkloosheidsgegevens zou de gebruikswaarde van de beschikbare PGI-informatie in belangrijke mate kunnen doen toenemen. De vacature- en werkloosheidsgegevens zouden enerzijds kunnen worden gebruikt voor het verder verbijzonderen van de doelstellingen van het Regionaal Meerjaren Beleidsplan (zie figuur 3.1 en 3.2), de bemiddelingskansen (zie figuur 3.3) en de vanuit de Arbeidsvoorzieningsoptiek gewenste scholingstrajecten (zie figuur 3.4). Anderzijds zou de informatie waardevol kunnen zijn voor de evaluatie van het Regionaal Meerjaren Beleidsplan (zie figuur 3.2). Zoals reeds eerder werd aangegeven vereist een integratie van de interne en externe arbeidsmarktinformatie het ontwikkelen van schakelschema's tussen de gehanteerde classificaties.

Ook voor dit derde vervolgtraject zou vanwege het ontbreken van schaalvoordelen in het ontwikkeltraject de voorkeur uitgaan naar het opzetten van een pilot-studie met betrekking tot de beide Limburgse RBA's c.q. één van beide RBA-regio's.

\section{Vaststellen gewenste scholingstrajecten en selectie van de te scholen werkzoekenden}

Ter completering van de vereiste arbeidsmarktinformatie ten behoeve van het scholingsbeleid, zal in de eerste plaats getracht moeten worden op basis van de hierboven reeds genoemde informatie te komen tot een vaststelling van de vanuit de Arbeidsvoorzieningsoptiek gewenste scholingstrajecten binnen de RBA-regio. Daarnaast zal met behulp van informatie over het interne en externe rendement van het huidige aanbod van cursussen en vakopleidingen, in samenhang met het geformuleerde doelgroepenbeleid, de voor de Arbeidsvoorzieningsorganisatie vereiste informatie dienen te worden gegenereerd ten behoeve van de (eerste) selectie van de te scholen werkzoekenden (zie figuur 3.4).

Ook hier zou vanwege het ontbreken van substantiële schaalvoordelen bij een grootschalige aanpak, in eerste instantie gedacht kunnen worden aan een pilot-studie met betrekking tot (één van) beide Limburgse RBA-regio's.

Op basis van de bovenstaande vier mogelijke vervolgtrajecten wordt de in de figuren 3.1-3.4 geschetste vereiste inhoud van het RAIS ten behoeve van de regionale Arbeidsvoorzieningsorganisatie volledig ingevuld. Op basis van deze vervolgtrajecten kan het RAIS, zoals gezegd, steeds verder worden uitgebouwd, waarbij telkens ook feitelijke arbeidsmarktinformatie beschikbaar komt. Daarbij zou er voor kunnen worden gekozen de vervolgtrajecten stapsgewijze uit te voeren. Evengoed is het echter mogelijk (een deel van) de geschetste vervolgactiviteiten in onderlinge combinatie uit te voeren. 


\section{LITERATUUR}

Arbeidsvoorziening (1993A), Hoe werven bedrijven 1992, OAV-Rapport 93-01, Rijswijk.

Arbeidsvoorziening (1993B), Hoe zoeken werkzoekenden in 1992, OAV-Rapport 93-02, Rijswijk.

Bakker, B.F.M., P.A.H. Andela, J.K. Jonker, J.A. Oud, L.G. Zwarenstein (1993), Ontwerp van de CBS Standaard Beroepen Classificatie 1992, CBS, interne notitie, Voorburg.

Buist, D., M. Vermeulen (1992), Een model voor de voorspelling van het Regionaal Arbeidsaanbod, INRO-TNO, Delft.

Berendsen, H., A. de Grip, M.H. Wieling, E.J.T.A. Willems (1992-I), Regionale arbeidsmarktinformatie naar opleiding en beroep. Een verkenning vanuit het ROA-informatiesysteem onderwijsarbeidsmarkt, ROA-R-1992/2, Maastricht.

Berendsen, H., A. de Grip, M.H. Wieling, E.J.T.A. Willems (1992-II), Arbeidsmarktinformatie naar opleiding en beroep voor de provincie Noord-Holland, ROA-R-1992/3, Maastricht.

Grip, A. de (1987), Onderwijs en arbeidsmarkt: scholingsdiscrepatie, VU-uitgeverij, Amsterdam.

Grip, A. de (1991), Meer licht op de regionale arbeidsmarkt, ROA-R-1991/4, Maastricht.

Grip, A. de, P. Meijboom, E.J.T.A. Willems (1993) Vacancies, Employment Growth and the Demand for Newcomers on the Labour Market, ROA-RM-1993/1E, Maastricht.

Hoevenberg, J. E.J.T.A. Willems, A. de Grip (1993), Actuele arbeidsmarktinformatie voor de regio Rijnmond, ROA-R-1993/5, Maastricht.

Laan, L. van der (1992), Regionale arbeidsmarktinformatie, EGI-Onderzoekspublikatie 05, EGI, Erasmus Universiteit Rotterdam, Rotterdam.

Natzijl, H.P., P. Westra (1993), Regionale arbeidsmarktprognose 1993-1998, OAV-rapport 9305, Rijswijk.

Nieuwland, R.K.M., A. de Grip (1993) Gebruikersonderzoek ROA-rapport 'De arbeidsmarkt naar opleiding en beroep' ROA-W-1993/2, Maastricht.

RDC-Limburg (1993A), RUBS 1992, Provinciale Rapportage Limburg, LBO-schoolverlaters (Jaargang 1990-'91).

RDC-Limburg (1993B), RUBS 1992, Provinciale Rapportage Limburg, (K)MBO-schoolverlaters 
(Jaargang 1990-'91).

RDC-Limburg (1993C), RUBS 1992, Provinciale Rapportage Limburg, MAVO-HAVO-VWOschoolverlaters ( Jaargang 1990/'91).

Schouten, W.J.C., A.L. van der Zwan (1993), Hoe zoeken werkzoekenden?, in: Economisch Statistische Berichten, jrg. 78, 21 april 1993, p. 363-366.

Tudoir, P.P., C. Maat, J.L.M. van Ineveld (1993), Regionale economische ontwikkelingen. Analyse op basis van ERBO data, INRO-TNO, Delft.

Wegerif, M. (1992), The use of vacancy data by the Dutch Employment Service, Paper presented in the workshop on measurement and analysis of vacancies in Maastricht, Rijswijk.

Wieling, M.H., R.J.P. Dekker, A. de Grip (1991), Landelijke en regionale werkloosheidsindicatoren 1991, ROA-R-1991/8, Maastricht.

Wieling M.H., P.J.E. van de Loo, R.K.W. van der Velden, (1993), Waar komen onze schoolverlaters terecht? De uitstroom en bestemming van het schooljaar 1990/1991, LDC, Leeuwarden. 


\section{BIJLAGE I. CONTACTPERSONEN}

G.M.J. Ahn

Drs. W. Derks

Drs. P.M.P.J. Gielen

Drs. Th. Mensen

H.J. Schotanus

T.M.J. Simons
Arbeidsbureau Oostelijke Mijnstreek

ETIL

GMD Maastricht

RBA Zuid-Limburg

Kamer van Koophandel en Fabrieken voor de Mijnstreek

GMD Maastricht 